\title{
Resistance of Wheat Genotypes to Root-Lesion Nematode (Pratylenchus thornei) Can be Used to Predict Final Nematode Population Densities, Crop Greenness, and Grain Yield in the Field
}

\author{
J. P. Thompson, $†$ J. G. Sheedy, and N. A. Robinson \\ University of Southern Queensland, Centre for Crop Health, Institute for Agriculture and the Environment, West Street, Toowoomba, QLD \\ 4350, Australia \\ Accepted for publication 29 October 2019.
}

ABSTRACT

\begin{abstract}
The root-lesion nematode Pratylenchus thornei is a major pathogen of wheat (Triticum aestivum) in many regions globally. Resistance of wheat genotypes to $P$. thornei can be determined from final nematode population densities in glasshouse experiments but combining results across multiple experiments presents challenges. Here, we use a factor analytic method for multiexperiment analysis of final population densities of $P$. thornei for 1,096 unique wheat genotypes in 22 glasshouse experiments. The resistance to $P$. thornei of the genotypes was effectively represented by a two-factor model with rotation of the axes to a principal components solution. Principal axes 1 and 2 (PA1 and PA2) accounted for 79 and $11 \%$ of the genetic variance, respectively, over all experiments. Final population densities of $P$. thornei as empirical best linear unbiased predictors $(\mathrm{PA}[1+2]$-eBLUPs) from the combined glasshouse experiments were highly predictive $(P<0.001)$ of final nematode population densities in the soil profile, crop canopy greenness (normalized difference
\end{abstract}

vegetation index), and grain yield of wheat genotypes in P. thorneiinfested fields in the Australian subtropical grain region. Nine categories of resistance ratings for wheat genotypes from resistant to very susceptible were based on subdivision of the range of PA(1+2)eBLUPs for use in growers' sowing guides. Nine genotypes were nominated as references for future resistance experiments. Most (62\%) Australian wheat genotypes were in the most susceptible three categories (susceptible, susceptible to very susceptible, and very susceptible). However, resistant germplasm characterized in this study could be used in plant breeding to considerably improve the overall resistance of Australian wheat crops.

Keywords: disease control and pest management, genetics and resistance, MET analysis, nematode population densities predictions, nematology, root-lesion nematodes, wheat genotype resistance, wheat yield prediction
The root-lesion nematode Pratylenchus thornei is a major pathogen of wheat (Triticum aestivum) in many regions of the world (Smiley and Nicol 2009), particularly subtropical and warm temperate zones such as the subtropical or northern grain region of eastern Australia (Thompson et al. 2008; Webb et al. 1997). This region, which lies between latitude $20^{\circ} \mathrm{S}$ in Queensland and latitude $32^{\circ} \mathrm{S}$ in New South Wales, is characterized by rain-fed agriculture dependent on dryland farming practices, with a range of broad-acre crop species grown throughout the year. Major cool-season crops, termed winter crops, are wheat, barley (Hordeum vulgare), and chickpea (Cicer arietinum), while major warm-season crops, termed summer crops, are sorghum (Sorghum bicolor) and mung bean (Vigna radiata), with a number of other cereal, pulse, and oilseed crop species grown to lesser extents. Deep cracking clay soils (vertisols) are favored for cropping in this region because of their high water-holding capacities to store fallow rainfall to supplement rainfall during the next crop phase (Webb et al. 1997).

$P$. thornei is polyphagic, being hosted by many cereal and pulse crop species, including wheat and chickpea; which, in other

†Corresponding author: J. P. Thompson; john.thompson@usq.edu.au

Funding: We thank the Grains Research and Development Corporation of Australia for co-investment in this research through project USQ00019, and the Department of Agriculture and Fisheries Queensland for support under the Broadacre Agriculture Strategic Partnership with the University of Southern Queensland.

*The $\boldsymbol{e}$-Xtra logo stands for "electronic extra" and indicates that one supplementary table is published online.

The author(s) declare no conflict of interest.

(C) 2020 The American Phytopathological Society respects, are valuable rotational crops for each other. Some wheat genotypes can lose up to $65 \%$ yield (Thompson et al. 1999) and some chickpea genotypes up to $25 \%$ yield (Reen et al. 2014) from high population densities of $P$. thorne $i$ in the soil profile at sowing. It has been estimated that $P$. thornei costs $4.3 \%$ of the total wheat production/year in the eastern Australian subtropical grain region, with this loss valued at AU\$38 million (Murray and Brennan 2009). Other hosts of $P$. thornei among crop species grown in this region include winter crops barley, triticale ( $\times$ Triticosecale), durum (T. turgidum subsp. durum), and faba bean (Vicia faba), and summer crops mung bean, black gram (Vigna mungo), and soybean (Glycine max) (Owen et al. 2012, 2014).

Management of $P$. thornei for wheat production depends on crop sequences that include moderately resistant crop species such as sorghum (Owen et al. 2014; Thompson et al. 2008, 2012a), which is the major summer crop species in the subtropical grain region of Australia. However, sorghum cannot be grown profitably across the entire region. Fixed rotations are difficult to implement due to variable rainfall patterns in this region, and flexible crop sequencing (termed opportunity cropping) is often practiced. P. thornei survives well in the clay soils of the region and, following growth of a susceptible wheat cultivar, approximately 3 years of fallow or resistant rotational crops are needed to reduce high nematode population densities to below the threshold for damage (Owen et al. 2014; Whish et al. 2017), which is approximately 2,000 nematodes $/ \mathrm{kg}$ of soil for intolerant wheat cultivars (Thompson et al. 2008). Protection of the major at-risk crops through breeding resistant and tolerant genotypes is essential for the long-term management of $P$. thornei in this region.

Tolerance and resistance to nematodes are treated as separately measured characteristics in nematology. Tolerance is defined as the capacity of plant genotypes to grow and yield with little loss in the 
presence of high initial nematode population densities, and resistance is defined as the capacity of plant genotypes to limit nematode reproduction in the roots (Roberts 2002; Trudgill 1991). Although tolerance and resistance can be measured independently they are not necessarily independent characteristics. Roberts (2002) indicated that a resistant plant genotype may not only have low nematode population densities in its roots but also, as a consequence of the low population density, can have maximum plant growth at least equal to a tolerant genotype. In field experiments, $P$. thornei was shown to decrease the uptake by wheat plants of soil nutrients (Thompson et al. 2012a) and water (Whish et al. 2014) under both drier and wetter seasonal conditions than the long-term average. Previously, Wallace (1987) suggested that genetic factors that confer on plants the abilities to withstand stresses such as water and nutrient deficiencies would function in a nonspecific way to confer tolerance to nematode attack. On the other hand, genetic factors for resistance to nematodes are specific and, in fact, certain wheat genotypes resistant to $P$. thornei are susceptible to $P$. neglectus (Farsi et al. 1995; Thompson 2008). Similarly, other wheat genotypes resistant to cereal cyst nematode (Heterodera avenae) are susceptible to $P$. thornei (Nombela and Romero 2001; Romero and Nombela 1999; Thompson 2008).

Resistance to nematodes is measured by the increase in nematode population densities during plant growth. Resistance of crop genotypes to root-lesion nematodes can be assessed in the field or glasshouse, with the more resistant genotypes resulting in lower final population densities $\left(\mathrm{P}_{\mathrm{f}}\right)$ of nematodes than the more susceptible genotypes. The advantage of glasshouse methods is that the initial population density $\left(\mathrm{P}_{\mathrm{i}}\right)$ of a single nematode species can be made constant for all genotypes to be tested in an experiment whereas, under field conditions, the $\mathrm{P}_{\mathrm{i}}$ of the site for the target nematode species has to be determined from soil sampling (De Waele and Elsen 2002). Spatial variability of nematode population densities in a field can be a confounding factor that may require the $\mathrm{P}_{\mathrm{i}}$ of every plot in a field experiment to be determined (Fanning et al. 2018), thereby considerably increasing the resources needed. Furthermore, better environmental control is possible under glasshouse conditions, resulting in a greater proportion of experiments successfully completed with less variability between experiments. Another issue for assessing crop resistance to $P$. thorne $i$ in field experiments on vertisols is that the nematodes can be distributed down the soil profile to approximately $90 \mathrm{~cm}$ of depth with various vertical distribution patterns (Owen et al. 2014; Thompson et al. 1999), further complicating the determination of nematode population densities in the field.

Glasshouse-based methods have been used to characterize crop genotypes in replicated experiments for resistance to $P$. thornei, including advanced lines in wheat breeding programs (Thompson et al. 1999) and cultivars for growers' sowing guides (Lush 2018; Matthews et al. 2017). These methods have also been used as a single plant test for selecting resistant genotypes within segregating populations for breeding programs. These glasshouse methods were calibrated during initial development with field results by comparing final $P$. thornei population densities associated with four selected wheat genotypes grown in both the glasshouse and field (Thompson et al. 2015a,b). Over time, the glasshouse methods have been modified to provide conditions conducive for both plant growth and nematode reproduction so that differences in the $\mathrm{P}_{\mathrm{f}}$ among genotypes are controlled by genetic difference rather than environmental factors.

Resistance of a wheat genotype in the glasshouse method is assessed after 16 weeks of plant growth by the final nematode population density in the roots and soil, because $P$. thornei can migrate between the roots and soil. Reference or check genotypes that cover a range of resistance and susceptibility are included in each experiment for comparison with new genotypes to be tested and to gauge nematode reproduction in an experiment. This method allows ranking of genotypes on their resistance in any single experiment but presents difficulties in comparing results across multiple unbalanced experiments in which many of the genotypes under consideration differ from experiment to experiment. This lack of balance arises from the ongoing need to characterize the resistance of a changing suite of advanced plant breeding lines prior to their potential release to growers. To combine results across experiments, we previously used the average reproduction factor $(\mathrm{RF})=\mathrm{P}_{\mathrm{f}} / \mathrm{P}_{\mathrm{i}}$. The range of average $\mathrm{RF}$ was then divided into nine arithmetically equal categories to produce resistance ratings of cultivars for sowing guides. Nine categories are used in Australian sowing guides, ranging from resistant (R) to very susceptible (VS) (Lush 2018), known as an alpha rating scale to distinguish it from previous methods of assigning numbers 1 to 9 to these ordinal categories. Despite standardized experimental conditions, nematode reproduction rates can vary among experiments. This results in higher average RF values and susceptibility ratings of genotypes present in experiments with higher $\mathrm{P}_{\mathrm{f}}$ but absent from experiments with lower $\mathrm{P}_{\mathrm{f}}$, and vice versa. Clearly, a more rigorous statistical approach is required in order to compare the resistance to $P$. thornei of large numbers of wheat genotypes assessed across multiple glasshouse experiments.

In a previous study with chickpea, a factor analytic (FA) approach was used for a combined analysis of 10 glasshouse experiments that assessed resistance to $P$. thornei of 531 genotypes of chickpea, related wild species $(C$. reticulatum, $C$. echinospermum, and C. bijugum), and interspecific hybrids (Thompson et al. 2011). This FA approach was based on methods developed for multienvironment trial (MET) analysis of crop yields in regional field trials (Smith et al. 2001). In the context of glasshouse studies, experiments are dealt with similarly to environments in MET analyses. Genotype-experiment $(\mathrm{G} \times \mathrm{E})$ interaction effects are modeled by an FA regression model in a mixed-model framework. This is in order to accommodate heterogeneity of genetic variance across experiments and heterogeneity of covariance and, hence, correlation between experiments, while adjusting for spatial trends. These data sets from multiple glasshouse experiments on genotypes conducted over a period of years are typically unbalanced with respect to the occurrence of genotypes among experiments, and can involve large numbers of both genotypes and experiments. This is similar to the large numbers of genotypes and environments usually encountered in MET data (Cullis et al. 2010). The dimensionality of the data defined by the number of experiments can be reduced by FA models to a number of underlying factors. Best linear unbiased predictors (BLUPs) (Piepho 1998; Robinson 1991) of nematode population density for the genotypes are obtained from the variance parameter estimates. This FA approach has been shown to provide improved prediction of genotype performance relative to traditional variance component models and is also superior to conducting separate analysis of individual experiments (Kelly et al. 2007).

In this article, we apply FA methods for a combined analysis of 22 replicated glasshouse experiments conducted from 1996 to 2015 that were designed to characterize the resistance to $P$. thornei of a large number of genetically fixed genotypes of wheat. We further show that this approach to combining glasshouse resistance experiments provides a single strong predictor of relative $\mathrm{P}_{\mathrm{f}}$ of $P$. thornei, crop growth, and grain yield associated with specific wheat genotypes grown in $P$. thornei-infested fields. This provides a validated new method for ranking cereal genotypes on resistance to P. thornei for wheat improvement purposes and for growers' sowing guides.

\section{MATERIALS AND METHODS}

Glasshouse experiments. The data analyzed are from a series of experiments that we have conducted annually to characterize resistance to $P$. thornei of advanced wheat lines for plant breeding programs and wheat cultivars for growers' sowing guides. Data from 22 glasshouse experiments on resistance to P. thornei of 1,096 unique wheat genotypes were used for the combined analysis. 
Genotypes of other crops were present in some of these experiments; namely durum, barley, and triticale. Canary grass (Phalaris canariensis 'Moroccan') as a resistant crop control and an unplanted soil control were also included in some experiments. The number of genotypes, experimental designs, and any differences in experimental procedures for the experiments in each year are given in Table 1.

Glasshouse experimental methods. In each experiment, single plants of each genotype were grown for 16 weeks in three replicate pots of soil, a black Vertosol (Isbell 1996) of the Irving Series (Thompson and Beckmann 1959) containing 78\% clay from Wellcamp (latitude $27.55^{\circ} \mathrm{S}$, longitude $151.87^{\circ} \mathrm{E}$, elevation approximately $500 \mathrm{~m}$, near Toowoomba, QLD, Australia). In experiments from 1996 to 2012 , the soil was pasteurized at $70^{\circ} \mathrm{C}$ for $30 \mathrm{~min}$ to kill nematodes (Thompson 1990a) and fungal pathogens such as Fusarium pseudograminearum (Thompson 1990b) that might damage the plants and thereby limit Pratylenchus thornei reproduction. In later experiments (2013 to 2015), the temperature of pasteurization was increased to $85^{\circ} \mathrm{C}$ to ensure control of Pythium spp. originating from oospores (PennState Extension 2017). Each pot of soil was inoculated at sowing with a suspension of $P$. thornei at a rate of 10,000 nematodes $/ \mathrm{kg}$ of soil (oven dry equivalent) extracted from open-pot cultures on wheat (O'Reilly and Thompson 1993). The strain of $P$. thornei was originally isolated from Formartin, QLD, Australia (latitude $27.46^{\circ} \mathrm{S}$, longitude $151.43 \mathrm{E}$, elevation $364 \mathrm{~m}$ ). In the experiments conducted from 1996 to 1997, methods for pot culture with top watering, as described by Thompson and Haak (1997), were used. In experiments conducted from 1999 to 2015, methods for pot culture with bottom watering, as described by Sheedy and Thompson (2009), were used. A summary of conditions for each experiment is given in Table 1. Experiments were laid out on the glasshouse benches as three randomized complete blocks which had row-column spatial arrangements (Williams 1986), except in the first two experiments.

Water supply to the pots was ceased at approximately 15 weeks after sowing so that the soil dried down to approximately $45 \%$ moisture content in preparation for sampling at 16 weeks after sowing. This moisture content expedited processing of this soil type for nematode extraction. The soil and roots from each pot were placed in a tray where they were cut and broken manually into pieces of $<1 \mathrm{~cm}$, before thorough mixing. Soil moisture content was determined by drying a $150-\mathrm{g}$ subsample at $105^{\circ} \mathrm{C}$ in a forced-draft oven for $48 \mathrm{~h}$. Nematodes were extracted from 150-g subsamples of soil in Whitehead trays (Whitehead and Hemming 1965) for $48 \mathrm{~h}$ at $22^{\circ} \mathrm{C}$ and concentrated using a $20-\mu \mathrm{m}$ aperture sieve into approximately $15 \mathrm{ml}$ of water. $P$. thornei individuals were counted in a Peters 1-ml gridded slide (Chalex Corporation, Portland, OR, U.S.A.) under a compound microscope and population densities were expressed as number per kilogram of soil on an oven dry weight basis.

Field experiments. $\mathrm{P}_{\mathrm{f}}$ of $P$. thornei in the soil profile following the growth of wheat genotypes in field experiments and canopy greenness and grain yield were used to validate the glasshouse assessments of resistance or susceptibility of wheat genotypes.

Two field experiments to assess advanced wheat breeding lines in comparison with existing cultivars were conducted in 2001 on a Black Vertosol of the Bongeen soil type (Harris et al. 1999) containing $60 \%$ clay near Macalister, Australia (latitude $27.03^{\circ} \mathrm{S}$, longitude $151.07^{\circ} \mathrm{E}$, elevation $337 \mathrm{~m}$ ). Experiment 1 had 23 latematurity wheat genotypes while experiment 2 had 52 main-maturity wheat genotypes, each with three replications. Both experiments were laid out in the field in three blocks as a row-column design

TABLE 1. Aspects of methods used for glasshouse experiments to assess wheat genotypes for resistance to Pratylenchus thornei

\begin{tabular}{|c|c|c|c|c|c|c|c|c|}
\hline \multirow[b]{2}{*}{$\operatorname{Exp}^{b}$} & \multirow[b]{2}{*}{ Genotypes $^{\mathrm{c}}$} & \multicolumn{2}{|c|}{ Experimental design $^{a}$} & \multirow[b]{2}{*}{ Water ${ }^{\mathrm{d}}$} & \multirow[b]{2}{*}{ Nutrient $\mathrm{e}^{\mathrm{e}}$} & \multirow[b]{2}{*}{$\mathrm{Temp}^{\mathrm{f}}$} & \multirow[b]{2}{*}{ Nematodes } & \multirow[b]{2}{*}{ Mode $^{h}$} \\
\hline & & Rows & Columns & & & & & \\
\hline 1996 & 111 & $\mathrm{RB}$ & $\mathrm{RB}$ & Top & Solution & No & 2,500 & In soil \\
\hline 1997 & 90 & $\mathrm{RB}$ & $\mathrm{RB}$ & Top & Solution & No & 2,500 & In soil \\
\hline 1999 & 125 & $\mathrm{RC}$ & $\mathrm{RC}$ & Bottom & Solution & Yes & 10,000 & Suspension \\
\hline 2000 & 126 & $\mathrm{RC}$ & $\mathrm{RC}$ & Bottom & Solution & Yes & 10,000 & Suspension \\
\hline 2001 & 118 & $\mathrm{RC}$ & $\mathrm{RC}$ & Bottom & Solution & Yes & 10,000 & Suspension \\
\hline 2002 & 129 & 10 & 39 & Bottom & Solution & Yes & 10,000 & Suspension \\
\hline 2003 & 154 & 11 & 42 & Bottom & Osmocote & Yes & 10,000 & Suspension \\
\hline 2005 & 143 & 18 & 24 & Bottom & Osmocote & Yes & 10,000 & Suspension \\
\hline 2006 & 139 & 18 & 24 & Bottom & Osmocote & Yes & 10,000 & Suspension \\
\hline 2007 & 228 & 29 & 24 & Bottom & Osmocote & Yes & 10,000 & Suspension \\
\hline 2008 & 27 & 9 & 9 & Bottom & Osmocote & Yes & 10,000 & Suspension \\
\hline $2009 C$ & 45 & 9 & 15 & Bottom & Osmocote & Yes & 10,000 & Suspension \\
\hline $2009 N$ & 117 & 13 & 27 & Bottom & Osmocote & Yes & 10,000 & Suspension \\
\hline $2010 \mathrm{C}$ & 156 & 36 & 13 & Bottom & Osmocote & Yes & 10,000 & Suspension \\
\hline $2010 \mathrm{~N}$ & 156 & 36 & 13 & Bottom & Osmocote & Yes & 10,000 & Suspension \\
\hline $2011 C$ & 110 & 11 & 30 & Bottom & Osmocote & Yes & 10,000 & Suspension \\
\hline $2011 N$ & 156 & 39 & 12 & Bottom & Osmocote & Yes & 10,000 & Suspension \\
\hline $2012 C$ & 110 & 33 & 10 & Bottom & Osmocote & Yes & 10,000 & Suspension \\
\hline $2012 \mathrm{~N}$ & 143 & 39 & 11 & Bottom & Osmocote & Yes & 10,000 & Suspension \\
\hline 2013 & 144 & 36 & 12 & Bottom & Osmocote & Yes & 10,000 & Suspension \\
\hline 2014 & 110 & 33 & 10 & Bottom & Osmocote & Yes & 10,000 & Suspension \\
\hline 2015 & 120 & 36 & 10 & Bottom & Osmocote & Yes & 10,000 & Suspension \\
\hline
\end{tabular}

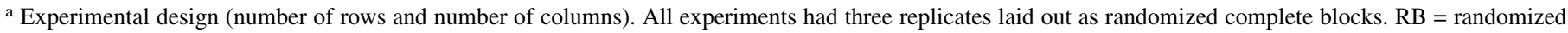

block design only and $\mathrm{RC}=$ additional row column design but exact positions not available for the combined analysis of experiments.

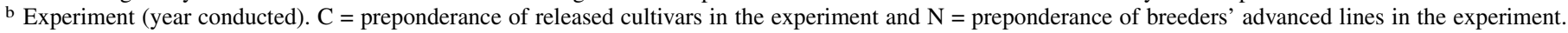

c Number of genotypes.

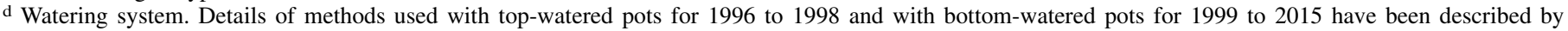
Thompson and Haak (1997) and Sheedy and Thompson (2009), respectively. For top watering, the soil was brought to 56\% moisture content as required whereas, for bottom watering, the soil was held at a constant $2 \mathrm{~cm}$ of water tension.

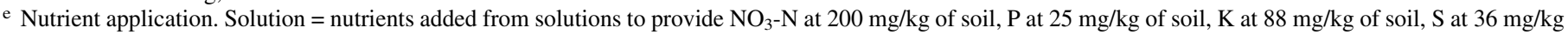
of soil, Ca at $285 \mathrm{mg} / \mathrm{kg}$ of soil, and $\mathrm{Zn}$ at $5 \mathrm{mg} / \mathrm{kg}$ of soil. Osmocote $=1 \mathrm{~g}$ of Osmocote native gardens plus micronutrients (17:1.6:8.7 N-P-K) slow-release fertilizer pellets (Scotts Australia Pty Ltd., Baulkham Hills, Australia).

f Under-bench control of soil temperature at $22^{\circ} \mathrm{C}$.

g Inoculum (nematodes per kilogram of soil).

h Inoculum mode. 
(Williams 1986), with plots being $8 \mathrm{~m}$ long by seven drill rows on $25-\mathrm{cm}$ spacing. The plots were fertilized with $\mathrm{N}$ at $55 \mathrm{~kg} / \mathrm{ha}$ as urea before sowing, and with Starter Z (Granulock Z, Incitec Pivot) at $40 \mathrm{~kg} / \mathrm{ha}$ supplying $\mathrm{N}$ at $4.4 \mathrm{~kg} / \mathrm{ha}, \mathrm{P}$ at $8.7 \mathrm{~kg} / \mathrm{ha}, \mathrm{S}$ at $1.6 \mathrm{~kg} / \mathrm{ha}$, and $\mathrm{Zn}$ at $0.4 \mathrm{~kg} / \mathrm{ha}$ applied with the seed at sowing. Seeding rate was adjusted based on grain weight and germination percentage of each genotype to sow 100 viable seeds $/ \mathrm{m}^{2}$. The cropping history of the land immediately prior to the experiments was wheat cultivar Hybrid Mercury, double cropped to black gram cultivar Regur ( $V$. mungo), then clean fallowed until the wheat experiments were sown 14 months later. During the course of the wheat growing season, symptoms of damage from root-lesion nematodes were noted on some of the $P$. thornei-intolerant cultivars in the experiments. Therefore, after grain was harvested by machine, the three replicate plots of a subset of genotypes (11 in experiment 1 and 19 in experiment 2) were soil sampled to assess $P_{f}$ of root-lesion nematodes. Deep soil samples were taken with a vehicle-mounted hydraulic soil corer using push tubes of $45 \mathrm{~mm}$ in diameter. Four positions were sampled per plot from the middle rows at approximately even intervals along the harvested length of $6 \mathrm{~m}$ of each plot. The four soil cores were subdivided and composited into one bulk in each of the following layers- 0 to 15,15 to 30,30 to 45 , 45 to 60,60 to 90,90 to 120 , and 120 to $150 \mathrm{~cm}$ of depth-and placed in polythene bags. The soil was broken into pieces manually and mixed thoroughly, a 100-g subsample was oven dried to determine soil water content, and another 150 -g subsample was extracted in Whitehead trays to determine nematode population densities. P. thornei was identified (Fortuner 1977) and counted as described above.

A field experiment to assess normalized difference vegetation index (NDVI) as a measure of the tolerance of wheat genotypes to P. thornei conducted in 2013 (Robinson et al. 2019) was also used to validate the glasshouse resistance experiments. This experiment was located on a Black Vertosol of the Waco series (Beckmann and Thompson 1960) with 70\% clay, near Formartin. The land was managed in a 4-year rotation of sorghum, long fallow, bulk wheat, wheat experimental plots, then long fallow back to bulk sorghum, as described previously (Thompson et al. 1999). The partially resistant wheat line QT8343 and the susceptible wheat cultivar Kennedy were grown in a three-replicate strip design as the first wheat crop in the 4-year rotation to generate low and high $P$. thornei population densities, respectively. All test wheat cultivars were sown into both low (P. thornei at 2,570 individuals $/ \mathrm{kg}$ of soil at 0 to $90 \mathrm{~cm}$ from back-transformation of $\ln [x+1]$ mean, where $\ln =$ natural logarithm or $\log _{\mathrm{e}}$ where $e$ is Euler's number, following QT8343) and high $(9,090$ individuals $/ \mathrm{kg}$ of soil at 0 to $90 \mathrm{~cm}$ from back-transformation of $\ln [x+1]$ mean following cultivar Kennedy) population densities in the following year (Robinson et al. 2019). Other field procedures were similar to those described for Macalister, except the rate of urea applied before sowing supplied $\mathrm{N}$ at $100 \mathrm{~kg} / \mathrm{ha}$ to each crop.

After grain harvest in November, the soil was sampled by taking two cores/plot with a hydraulically driven push tube to $90 \mathrm{~cm}$ of depth at one-third intervals along the plot, and subdivided and composited in intervals of 0 to 30,30 to 60 , and 60 to $90 \mathrm{~cm}$. Nematode population densities and soil water contents were determined as described above for the Macalister experiments.

Statistical analysis of glasshouse experiments. A consideration for the estimation of parameters in a multiexperiment model is the concurrence of genotypes; that is, the number of genotypes in common between pairs of experiments (Table 2). Most pairs of glasshouse experiments had suitable numbers of concurrent genotypes, except for the experiment $2009 \mathrm{~N}$, which had only two genotypes in common with eight other experiments (Table 2). The data on final $P$. thornei population densities were transformed by natural logarithms to ensure homogeneity of variance over the range of fitted values. The multiexperiment analysis modeled $\ln (P$. thornei nematodes $/ \mathrm{kg}$ of soil +1$)$ in a linear mixed-model framework, following the approach of Smith et al. (2001). A fixed term was included for experiment effects and a random term was included for replicate effects for all experiments. An FA variance structure was fitted to the $\mathrm{G} \times \mathrm{E}$ effects, allowing for a different genetic variance for each experiment, and heterogeneous covariance (and hence correlation) between each pair of experiments. Spatial location of the pots in the two-dimensional arrangement on the glasshouse benches was fitted through a spatial correlation process across rows and columns (where significant for experiments from 2002 to 2015) following the approach of Gilmour et al. (1997). Random terms for row and column effects were included through the spatial modeling process, where significant. A crop-type factor was included in the analysis as a fixed effect to account for wheat, durum, barley, triticale, canary grass, and unplanted control.

The FA model was extended by including higher order terms in the model, until at least $90 \%$ of the genetic variance over all experiments was explained. The effective number of dimensions of the FA model was then tested with the Akaike information criterion as used by Beeck et al. (2010) and by assessing the percentage of

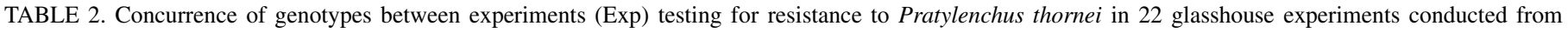
1996 to $2015^{\mathrm{a}}$

\begin{tabular}{|c|c|c|c|c|c|c|c|c|c|c|c|c|c|c|c|c|c|c|c|c|c|c|}
\hline Exp & 1996 & 1997 & 1999 & 2000 & 2001 & 2002 & 2003 & 2005 & 2006 & 2007 & 2008 & $2009 C$ & $2009 \mathrm{~N}$ & $2010 \mathrm{C}$ & $2010 \mathrm{~N}$ & $2011 C$ & $2011 N$ & $2012 \mathrm{C}$ & $2012 \mathrm{~N}$ & 2013 & 2014 & 2015 \\
\hline 1996 & 111 & $\ldots$ & $\ldots$ & $\ldots$ & $\ldots$ & $\ldots$ & $\ldots$ & $\ldots$ & $\ldots$ & $\ldots$ & $\ldots$ & $\ldots$ & $\ldots$ & $\ldots$ & $\ldots$ & $\ldots$ & $\ldots$ & $\ldots$ & $\ldots$ & $\ldots$ & $\ldots$ & $\ldots$ \\
\hline 1997 & 22 & 90 & $\ldots$ & $\ldots$ & $\ldots$ & $\ldots$ & $\ldots$ & $\ldots$ & $\ldots$ & $\ldots$ & $\ldots$ & $\ldots$ & $\ldots$ & $\ldots$ & $\ldots$ & $\ldots$ & $\ldots$ & $\ldots$ & $\ldots$ & $\ldots$ & $\ldots$ & $\ldots$ \\
\hline 1999 & 33 & 24 & 125 & $\ldots$ & $\ldots$ & $\ldots$ & $\ldots$ & $\ldots$ & $\ldots$ & $\ldots$ & $\ldots$ & $\ldots$ & $\ldots$ & $\ldots$ & $\ldots$ & $\ldots$ & $\ldots$ & $\ldots$ & $\ldots$ & $\ldots$ & $\ldots$ & $\ldots$ \\
\hline 2000 & 29 & 20 & 54 & 126 & $\ldots$ & $\ldots$ & $\ldots$ & $\ldots$ & $\ldots$ & $\ldots$ & $\ldots$ & $\ldots$ & $\ldots$ & $\ldots$ & $\ldots$ & $\ldots$ & $\ldots$ & $\ldots$ & $\ldots$ & $\ldots$ & $\ldots$ & $\ldots$ \\
\hline 2001 & 27 & 21 & 45 & 63 & 118 & $\ldots$ & $\ldots$ & $\ldots$ & $\ldots$ & $\ldots$ & $\ldots$ & $\ldots$ & $\ldots$ & $\ldots$ & $\ldots$ & $\ldots$ & $\ldots$ & $\ldots$ & $\ldots$ & $\ldots$ & $\ldots$ & $\ldots$ \\
\hline 2002 & 34 & 27 & 39 & 47 & 69 & 129 & $\ldots$ & $\ldots$ & $\ldots$ & $\ldots$ & $\ldots$ & $\ldots$ & $\ldots$ & $\ldots$ & $\ldots$ & $\ldots$ & $\ldots$ & $\ldots$ & $\ldots$ & $\ldots$ & $\ldots$ & $\ldots$ \\
\hline 2003 & 29 & 21 & 32 & 34 & 38 & 56 & 154 & $\ldots$ & $\ldots$ & $\ldots$ & $\ldots$ & $\ldots$ & $\ldots$ & $\ldots$ & $\ldots$ & $\ldots$ & $\ldots$ & $\ldots$ & $\ldots$ & $\ldots$ & $\ldots$ & $\ldots$ \\
\hline 2005 & 21 & 15 & 27 & 31 & 33 & 36 & 43 & 143 & $\ldots$ & $\ldots$ & $\ldots$ & $\ldots$ & $\ldots$ & $\ldots$ & $\ldots$ & $\ldots$ & $\begin{array}{l}\cdots \\
\ldots\end{array}$ & $\cdots$ & $\begin{array}{l}\cdots \\
\ldots\end{array}$ & $\begin{array}{l}\ldots \\
\ldots\end{array}$ & $\ldots$ & $\begin{array}{l}\cdots \\
\ldots\end{array}$ \\
\hline 2006 & 24 & 15 & 28 & 32 & 34 & 38 & 41 & 87 & 139 & $\ldots$ & $\ldots$ & $\ldots$ & $\ldots$ & $\ldots$ & $\ldots$ & $\ldots$ & $\ldots$ & $\ldots$ & $\ldots$ & $\ldots$ & $\ldots$ & $\ldots$ \\
\hline 2007 & 24 & 15 & 28 & 31 & 33 & 38 & 37 & 66 & 98 & 228 & $\ldots$ & $\cdots$ & $\ldots$ & $\cdots$ & $\cdots$ & $\cdots$ & $\cdots$ & $\ldots$ & $\ldots$ & $\cdots$ & $\ldots$ & $\cdots$ \\
\hline 2008 & 4 & 4 & 4 & 4 & 4 & 5 & 7 & 11 & 19 & 20 & 27 & $\ldots$ & $\ldots$ & $\ldots$ & $\ldots$ & $\ldots$ & $\ldots$ & $\ldots$ & $\ldots$ & $\ldots$ & $\ldots$ & $\ldots$ \\
\hline $2009 \mathrm{C}$ & 17 & 12 & 20 & 21 & 25 & 30 & 30 & 27 & 29 & 33 & 9 & 45 & $\ldots$ & $\ldots$ & $\ldots$ & $\ldots$ & $\ldots$ & $\ldots$ & $\ldots$ & $\ldots$ & $\ldots$ & $\ldots$ \\
\hline $2009 \mathrm{~N}$ & 2 & 2 & 2 & 2 & 2 & 2 & 3 & 4 & 5 & 9 & 4 & 3 & 117 & $\ldots$ & $\ldots$ & $\ldots$ & $\begin{array}{l}\cdots \\
\ldots\end{array}$ & $\cdots$ & $\begin{array}{l}\cdots \\
\ldots\end{array}$ & $\cdots$ & $\begin{array}{l}\cdots \\
\ldots\end{array}$ & $\begin{array}{l}\cdots \\
\ldots\end{array}$ \\
\hline $2010 \mathrm{C}$ & 30 & 15 & 31 & 36 & 40 & 59 & 41 & 44 & 50 & 53 & 14 & 40 & 7 & 156 & $\cdots$ & $\begin{array}{l}\ldots \\
\ldots\end{array}$ & $\begin{array}{l}\cdots \\
\ldots\end{array}$ & $\cdots$ & $\begin{array}{l}\cdots \\
\ldots\end{array}$ & $\begin{array}{l}\ldots \\
\ldots\end{array}$ & $\ldots$ & $\begin{array}{l}\ldots \\
\ldots\end{array}$ \\
\hline $2010 \mathrm{~N}$ & 4 & 4 & 5 & 4 & 5 & 6 & 6 & 5 & 6 & 8 & 4 & 5 & 59 & 11 & 156 & $\ldots$ & $\begin{array}{l}\cdots \\
\ldots\end{array}$ & $\cdots$ & $\begin{array}{l}\cdots \\
\ldots\end{array}$ & $\begin{array}{l}\cdots \\
\ldots\end{array}$ & $\ldots$ & $\begin{array}{l}\ldots \\
\ldots\end{array}$ \\
\hline $2011 \mathrm{C}$ & 15 & 6 & 16 & 17 & 21 & 31 & 22 & 25 & 31 & 37 & 11 & 28 & 9 & 96 & 20 & 110 & $\ldots$ & $\ldots$ & $\ldots$ & $\ldots$ & $\ldots$ & $\ldots$ \\
\hline $2011 N$ & 5 & 5 & 5 & 4 & 5 & 5 & 14 & 4 & 5 & 6 & 4 & 4 & 24 & 11 & 70 & 11 & 156 & $\ldots$ & $\ldots$ & $\ldots$ & $\ldots$ & $\ldots$ \\
\hline $2012 C$ & 6 & 5 & 6 & 6 & 7 & 23 & 12 & 8 & 6 & 9 & 7 & 11 & 15 & 79 & 31 & 75 & 24 & 110 & $\ldots$ & $\ldots$ & $\ldots$ & $\ldots$ \\
\hline $2012 \mathrm{~N}$ & 4 & 4 & 5 & 4 & 5 & 5 & 8 & 4 & 5 & 5 & 4 & 4 & 8 & 11 & 41 & 11 & 66 & 11 & 143 & $\ldots$ & $\ldots$ & $\ldots$ \\
\hline 2013 & 7 & 5 & 6 & 6 & 7 & 21 & 8 & 8 & 6 & 8 & 7 & 10 & 12 & 60 & 32 & 53 & 36 & 75 & 53 & 144 & $\ldots$ & $\ldots$ \\
\hline 2014 & 7 & 5 & 7 & 5 & 6 & 13 & 5 & 4 & 5 & 5 & 4 & 5 & 2 & 27 & 14 & 20 & 21 & 27 & 41 & 73 & 110 & $\ldots$ \\
\hline 2015 & 8 & 4 & 6 & 5 & 6 & 7 & 6 & 5 & 6 & 6 & 4 & 5 & 2 & 17 & 14 & 14 & 19 & 14 & 36 & 59 & 69 & 120 \\
\hline
\end{tabular}

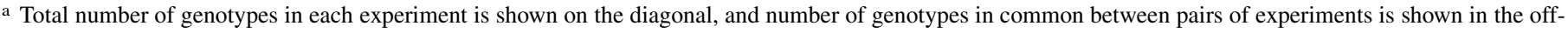
diagonal cells. 
variance accounted for by successively added factors. The estimated FA loadings were rotated to a principal components solution (Cullis et al. 2010), such that the first component axis accounted for the maximum amount of genetic covariance in the data and the second accounted for the next greatest amount, and so on for subsequent axes, and all the axes were orthogonal. A genetic correlation matrix between pairs of experiments was produced. The output from the FA analysis gave predictions of genotype performance in each experiment as regression empirical BLUPs (R-eBLUPs) (Cullis et al. 2010). For selected genotypes, the R-eBLUPs were plotted against loadings for principal axis 1 (PA1) of the individual experiments to produce a latent regression plot for which the slope is the PA1 score of that genotype (Smith et al. 2015). The overall resistance or susceptibility of genotypes was compared using a single value for each genotype as PA(1+2)-eBLUPs, where PAs are from the principal components solution. The PA(1+2)-eBLUP for each wheat genotype was calculated as the respective PA1 score multiplied by the average of the 22 rotated loadings for PA1 plus the respective PA2 score multiplied by the average of the 22 rotated loadings for PA2. These values were rescaled by addition of the estimate for the overall mean for wheat in units of $\ln (P$. thornei nematodes $/ \mathrm{kg}$ of soil +1$)$ and then back-transformed by exponentiation where required.

These statistical analyses were performed using ASReml-R (Butler et al. 2009) in the R software environment ( $\mathrm{R}$ Core Team 2016). Variance parameters were estimated using residual maximum likelihood estimation (Patterson and Thompson 1971).

Prediction of field $P_{f}$ of $P$. thornei from $P$. thornei resistance. The population densities of $P$. thornei in the field after harvest of the two experiments at Macalister and the experiment at Formartin were subject to analysis of variance by depth interval after transformation by $\ln (x+1)$. Significant differences were obtained among cultivars to $45 \mathrm{~cm}$ of depth at Macalister and $90 \mathrm{~cm}$ of depth at Formartin. Nonlinear regression analysis was conducted between the mean population densities of $P$. thornei in the soil profile ( 0 to $45 \mathrm{~cm}$ of depth at Macalister and 0 to $90 \mathrm{~cm}$ at Formartin) as response variables and PA(1+2)-eBLUPs of $\ln (P$. thornei nematodes $/ \mathrm{kg}$ of soil +1 ) from the combined glasshouse experiments as the explanatory variable using Genstat for Windows (VSN International 2014).

Prediction of NDVI and grain yield of wheat cultivars in field experiments from $P$. thornei resistance. The relationships between the grain yield of the cultivars in the three field experiments and the PA(1+2)-eBLUPs of $\ln (P$. thornei nematodes +1 ) from combined glasshouse experiments were examined graphically and appropriate nonlinear regression equations fitted in Genstat for Windows (VSN International 2014). Similarly, the relationships between the area under the disease progress curve (AUDPC) of seven readings of NDVI taken to measure vegetation greenness at intervals from 64 to 126 days after sowing of the genotypes in the Formartin experiment (Robinson et al. 2019) were determined.

Rating of resistance of wheat genotypes. The single range of log-transformed PA(1+2)-eBLUPs for the 1,096 wheat genotypes from MET analysis of the combined experiments was divided into nine equal subranges. Genotypes within these nine categories were assigned alpha ratings as used for diseases in Australian wheat variety guides for growers (Lush 2018; Matthews et al. 2017) as follows: $\mathrm{R}$, resistant to moderately resistant (R-MR), moderately resistant (MR), moderately resistant to moderately susceptible (MR-MS), moderately susceptible (MS), moderately susceptible to susceptible (MS-S), susceptible (S), susceptible to VS (S-VS), and VS.

\section{RESULTS}

Combined glasshouse experiments. A graphical display of the between-environments genetic correlation matrix between all pairs of 22 experiments from the MET analysis of $P$. thornei population densities of wheat genotypes is shown in Figure 1. The data from the experiments were well correlated, having $75 \%$ of all correlation coefficients between pairs of experiments $>0.70$ and with a median value of 0.80 . This shows strong agreement in relative nematode population densities for individual genotypes between experiments.

Predicted values from the FA model for experiment mean population density of $P$. thornei, genetic variance and error variance, as well as principal components loadings and percentage genetic variance accounted for by PA1 and PA2 in individual experiments, are shown in Table 3. An FA model of order 2 (designated FA-2) was retained as the final model, explaining $90 \%$ of the genetic variance over all experiments ( $79 \%$ by PA1 and $11 \%$ by PA2) (Table 3 ). The Akaike information criterion (value for FA-2 $=0$ compared with FA-1 $=10$ and FA-3 = 9) supported the decision to select the FA-2 model. Every experiment had at least $67 \%$ of genetic variance accounted for by this FA-2 model, and every experiment had $>55 \%$ genetic variance accounted for by PA1 alone, except for the 2006 experiment, with $42 \%$ (Table 3). Loadings along PA1 were positive for all experiments, ranging from 0.169 to 0.709 (Table 3). Loadings along PA2 ranged from -0.358 to 0.389 , with experiments having larger negative loadings being 2010N, 2009C, 2010C, 2008, and 2002, whereas experiments having larger positive loadings were 2012N, 2005, 1997, $2014,2015,2006$, and 2009N. There was no noticeable difference between these two groups of experiments in relation to the chronology of the experiments or variation of the method used (Table 1), or the mean final P. thornei population densities of the experiments (Table 3).

Latent regression plots of R-eBLUPs of population densities of $P$. thornei for PA1 against experiment loadings for the 22 experiments are shown for some selected reference genotypes in Figure 2. Genotypes with a positive slope or high PA1 score produced higher nematode densities in most experiments, while genotypes with a negative slope or low PA1 score produced lower nematode densities in most experiments. The deviation of R-eBLUPs from the line was an indication of additional variation for resistance of particular genotypes across the experiments measured in the dimension of PA2; that is, the PA2 score.

For genotypes that occurred in four or more experiments, scores for PA1 and PA2 and PA(1+2)-eBLUPs with probabilities of exceeding values of these for two reference genotypes are given in Supplementary Table S1, while these results for a subset of 60 genotypes mentioned in this article or present in the field experiments is given in Table 4.

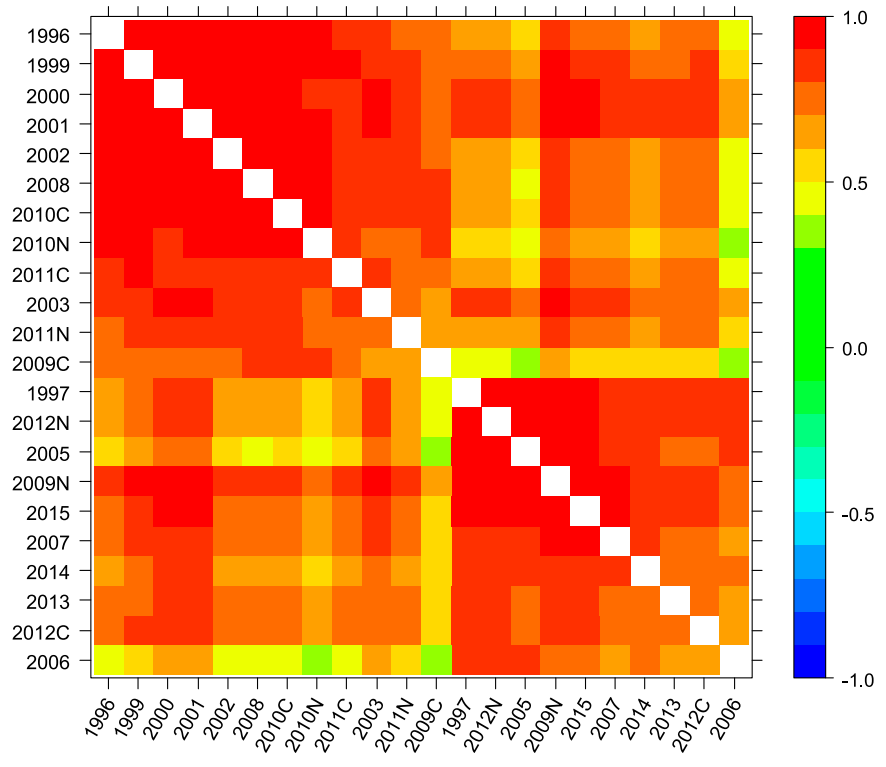

Fig. 1. Between-experiments genetic correlation matrix from the factor analytic (order 2) model for resistance testing of Pratylenchus thornei in 22 glasshouse experiments from 1996 to 2015. 
Relationship between field $P_{f}$ of $P$. thornei and resistance. In the Macalister field experiments, there were significant relationships for final $P$. thornei population densities at soil profile depths of 0 to 15,15 to 30 , and 30 to $45 \mathrm{~cm}$ but not at depths below $45 \mathrm{~cm}$ whereas, in the Formartin experiment, there were significant relationships at all depths of 0 to 30,30 to 60 , and 60 to $90 \mathrm{~cm}$ (not shown). There were highly significant $(P<0.001)$ linear relationships between the field population densities of $P$. thornei in the deep soil profile ( 0 to $45 \mathrm{~cm}$ at Macalister and 0 to $90 \mathrm{~cm}$ at Formartin) after growth of wheat genotypes in the three field experiments and the glasshouse-derived PA(1+2)-eBLUPs of those genotypes (Fig. 3).

Relationship between crop greenness at high and low population densities of $\boldsymbol{P}$. thornei and resistance. There were highly significant negative exponential relationships between AUDPC of NDVI measurements at both high and low P. thornei population densities in the field experiment at Formartin and glasshouse-derived PA(1+2)-eBLUPs of $P$. thornei population densities (Fig. 4).

Relationship between grain yield of wheat cultivars on $P$. thornei-infested sites and resistance. Grain yield of the wheat cultivars in the two field experiments at Macalister showed a significant negative sigmoidal relationship with glasshouse-derived measures of resistance of the same wheat cultivars expressed as PA(1+2)-eBLUPs of $\ln$ (population density of $P$. thornei nematodes/ $\mathrm{kg}$ of soil) from combined glasshouse experiments (Fig. 5). There were highly significant negative exponential relationships between grain yields at both high and low $P$. thornei population densities in the field experiment at Formartin and glasshouse-derived PA(1+2)eBLUPs of $P$. thornei population densities (Fig. 6A and B). Also, there was a highly significant exponential relationship between grain yield loss (calculated as the percentage difference in yields between low and high $P$. thornei population densities) in the field experiment at Formartin and glasshouse-derived PA(1+2)-eBLUPs of $P$. thornei population densities (Fig. 6C).

Resistance ratings of wheat genotypes. The $\mathrm{PA}(1+2)-$ eBLUPs of the 1,096 wheat genotypes (Table 4; Supplementary
Table S1) ranged from a minimum for CPI133872 (present in 13 experiments, with a back-transformed mean $\mathrm{P}_{\mathrm{f}}$ of 7,171 P. thornei nematodes/kg of soil) to a maximum for cultivar Darwin (present in 4 experiments, with a back-transformed mean $\mathrm{P}_{\mathrm{f}}$ of 104,192 P. thornei nematodes $/ \mathrm{kg}$ of soil) (Table 4). The distribution of the 1,096 wheat genotypes in this study in relation to the nine categories of resistance ratings based on subranges of PA(1+2)-eBLUPs is given in Figure 7.

Most of the wheat genotypes $(62 \%)$ tested in these experiments were in the three rating categories (S, S-VS, and VS) most susceptible to $P$. thornei. In contrast, only $2 \%$ of the wheat genotypes were in the most resistant three rating categories (R, MR-R, and MR). These most-resistant genotypes were mainly germplasm sources of resistance such as the synthetic hexaploid wheat CPI133872 (Thompson 2008; Zwart et al. 2004) or GS50a (a resistant selection from wheat cultivar Gatcher) (Thompson et al. 1999) and lines derived from back-crossing these into susceptible wheat cultivars; for example, QT8343 and QT9048 (Table 4). Two commercial cultivars, Impose CL Plus and Wyalkatchem, both adapted to the Mediterranean (western) grain region of Australia, were rated as MR. The category MR-MS included 10 named cultivars (Table 4), of which Gauntlet, Wallup, Sunmate, Suntime, Suntop, and Ventura are adapted to the subtropical (northern) grain region of eastern Australia, while Bolac, Kiora, Amarok, and Corack are adapted to the more temperate (southern) grain region of Australia. At the other end of the resistance spectrum were the VS wheat genotypes (Table 4), which included Petrie (a northern region cultivar), Brennan (a northern region forage wheat), and the southern region cultivars Darwin, Wedgetail, Annuello, and Forrest. The western region wheat cultivar Yandanooka, previously proposed as a VS reference cultivar (Sheedy et al. 2015), was categorized as S-VS in this study.

\section{DISCUSSION}

This is the first large-scale MET analysis of multiple glasshouse experiments to determine the resistance to $P$. thornei of an extensive range of wheat genotypes, in which the output has been used to

TABLE 3. Parameters from combined analysis using a factor analytic structure of 22 experiments (Exp) testing resistance to Pratylenchus thornei of wheat genotypes used for derivation of empirical best linear unbiased predictors of individual genotypes

\begin{tabular}{|c|c|c|c|c|c|c|c|c|c|}
\hline \multirow[b]{2}{*}{ Exp } & \multicolumn{2}{|c|}{$\begin{array}{c}\text { Mean } P . \text { thornei } \\
\text { nematodes/kg of soil }\end{array}$} & \multicolumn{2}{|c|}{ Variance } & \multicolumn{2}{|c|}{$\begin{array}{l}\text { Principal component } \\
\text { loadings }{ }^{b}\end{array}$} & \multicolumn{3}{|c|}{ Genetic variance accounted for $(\%)$} \\
\hline & $\ln (x+1)$ & ВТМ & Genetic & Error & PA1 & PA2 & PA1 & PA2 & $\mathrm{PA} 1+\mathrm{PA} 2$ \\
\hline 1996 & 10.663 & 42,753 & 0.046 & 0.169 & 0.196 & -0.044 & 83 & 4 & 88 \\
\hline 1997 & 10.965 & 57,804 & 0.105 & 0.270 & 0.277 & 0.169 & 73 & 27 & 100 \\
\hline 1999 & 11.981 & 159,764 & 0.303 & 0.357 & 0.542 & -0.097 & 97 & 3 & 100 \\
\hline 2000 & 11.063 & 63,759 & 0.503 & 0.636 & 0.709 & 0.004 & 100 & 0 & 100 \\
\hline 2001 & 12.092 & 178,504 & 0.336 & 0.379 & 0.579 & -0.039 & 100 & 0 & 100 \\
\hline 2002 & 11.945 & 154,095 & 0.180 & 0.266 & 0.394 & -0.106 & 87 & 6 & 93 \\
\hline 2003 & 10.597 & 39,995 & 0.435 & 1.438 & 0.602 & 0.034 & 83 & 0 & 84 \\
\hline 2005 & 11.528 & 101,478 & 0.175 & 0.574 & 0.328 & 0.260 & 61 & 39 & 100 \\
\hline 2006 & 11.564 & 105,263 & 0.068 & 0.815 & 0.169 & 0.141 & 42 & 29 & 71 \\
\hline 2007 & 12.510 & 271,020 & 0.193 & 0.541 & 0.387 & 0.099 & 78 & 5 & 83 \\
\hline 2008 & 11.226 & 75,026 & 0.127 & 0.368 & 0.331 & -0.132 & 86 & 14 & 100 \\
\hline $2009 C$ & 12.103 & 180,367 & 0.484 & 0.780 & 0.521 & -0.232 & 56 & 11 & 67 \\
\hline $2009 N$ & 12.313 & 222,542 & 0.271 & 0.647 & 0.507 & 0.117 & 95 & 5 & 100 \\
\hline $2010 \mathrm{C}$ & 12.327 & 225,763 & 0.407 & 0.777 & 0.597 & -0.224 & 88 & 12 & 100 \\
\hline $2010 \mathrm{~N}$ & 12.529 & 276,301 & 0.606 & 0.381 & 0.691 & -0.358 & 79 & 21 & 100 \\
\hline $2011 \mathrm{C}$ & 11.153 & 69,746 & 0.335 & 0.618 & 0.514 & -0.096 & 79 & 3 & 81 \\
\hline $2011 \mathrm{~N}$ & 11.492 & 97,959 & 0.520 & 0.308 & 0.613 & -0.056 & 72 & 1 & 73 \\
\hline $2012 \mathrm{C}$ & 10.069 & 23,590 & 0.441 & 1.019 & 0.571 & 0.108 & 74 & 3 & 76 \\
\hline $2012 \mathrm{~N}$ & 9.315 & 11,102 & 0.606 & 1.031 & 0.674 & 0.389 & 75 & 25 & 100 \\
\hline 2013 & 11.372 & 86,866 & 0.218 & 0.391 & 0.397 & 0.095 & 72 & 4 & 76 \\
\hline 2014 & 10.952 & 57,044 & 0.247 & 0.350 & 0.413 & 0.155 & 69 & 10 & 79 \\
\hline 2015 & 9.723 & 16,702 & 0.158 & 0.490 & 0.371 & 0.144 & 87 & 13 & 100 \\
\hline Overall & $\ldots$ & $\ldots$ & $\ldots$ & $\ldots$ & $\ldots$ & $\ldots$ & 79 & 11 & 90 \\
\hline
\end{tabular}

a Abbreviations: $\ln =$ natural logarithm or $\log _{\mathrm{e}}$ where $e$ is Euler's number and BTM = back-transformed mean by exponentiation

$\mathrm{b} \mathrm{PA}=$ principal axes after rotation to principal components solution. 
predict relative final nematode populations and grain yield of wheat genotypes in independent field experiments. We ranked more than 1,000 wheat genotypes for resistance to $P$. thornei by combining results from 22 experiments conducted during the period 1996 to 2015. This was achieved using an FA approach with rotation of axes to a principal components solution. A strong effect of wheat genotype on the $\mathrm{P}_{\mathrm{f}}$ of $P$. thornei in all experiments was exhibited in PA1, which can be considered a stable resistance axis accounting for $79 \%$ of the genetic variance. Furthermore, PA2, which accounted for an additional $11 \%$ of genetic variance, can be considered a measure of additional genetic variability for resistance across different experiments. One possible cause of the greater variability for resistance of some wheat genotypes could be incomplete genetic fixation of the genotype, whereas other genotypes might have been fixed through single plant selection and a greater number of inbred generations. Another possible reason is unidentified environmental variation among the experiments resulting in some $\mathrm{G} \times \mathrm{E}$ effects.

The overall predicted value for the $\mathrm{P}_{\mathrm{f}}$ of $P$. thornei based on PA(1+2)-eBLUPs from the FA-2 model can be considered the best single index for the resistance level of genotypes included in this investigation. A quantitative measure as used in this study rather

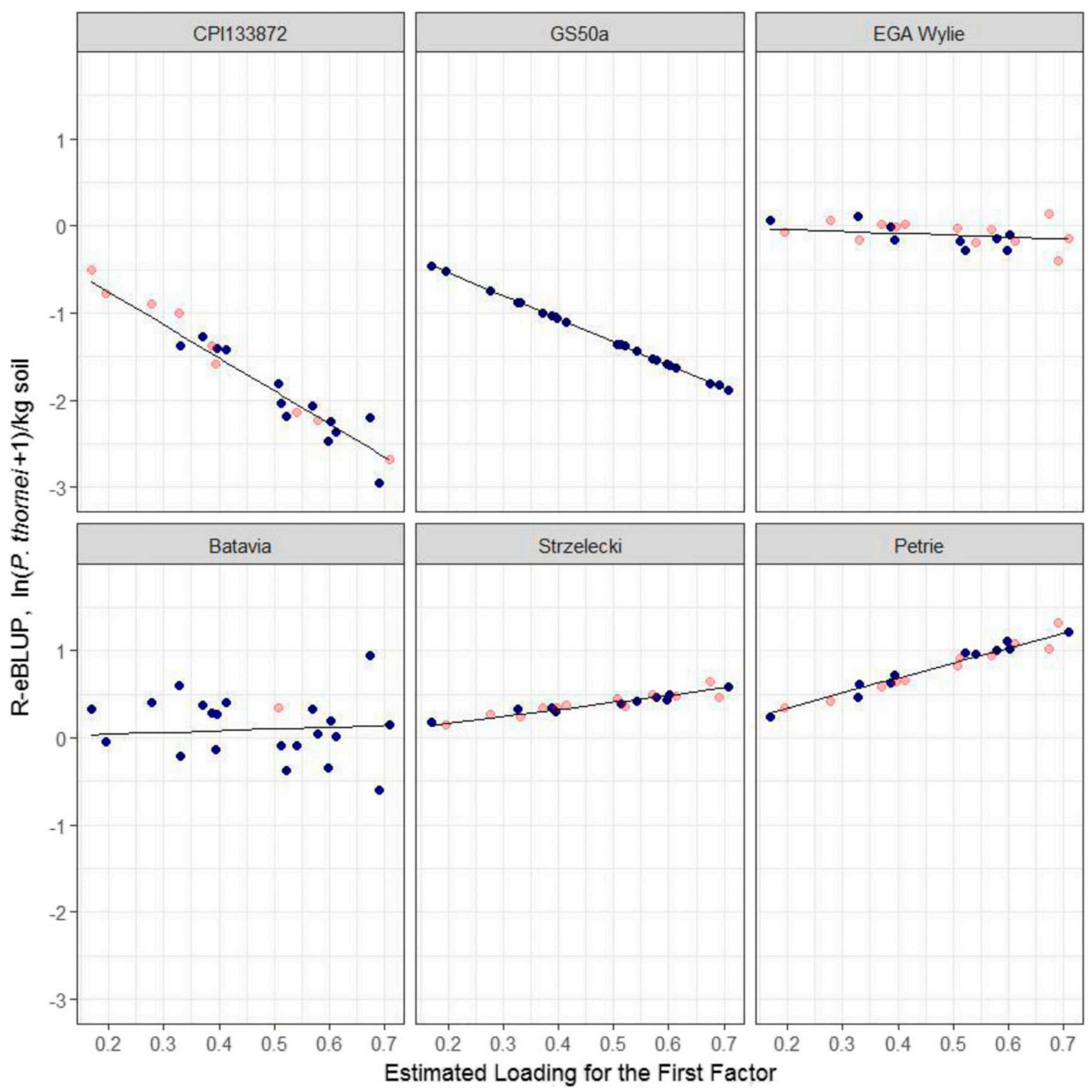

Fig. 2. Latent regression plots of predicted Pratylenchus thornei population density as regression empirical best linear unbiased predictors (R-eBLUPs) against estimated loadings for principal axis 1 (PA1) in 22 glasshouse experiments showing a selection of wheat genotypes with lower, intermediate, and higher nematode population densities and stabilities. Dark points indicate genotype present in the experiment associated with the loading, whereas light points indicate an estimate where genotype was absent from the experiment associated with the loading. 


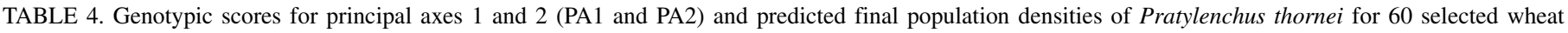
genotypes used in field experiments and present in 4 or more of 22 experiments comprising 1,096 wheat genotypes in a combined analysis ${ }^{\text {a }}$

\begin{tabular}{|c|c|c|c|c|c|c|c|c|c|}
\hline \multirow[b]{2}{*}{ Rank $^{\mathrm{b}}$} & \multirow[b]{2}{*}{ Genotype } & \multicolumn{2}{|c|}{ PA scores } & \multicolumn{2}{|c|}{ P. thornei nematodes $/ \mathrm{kg}$ of soil } & \multicolumn{2}{|c|}{$\begin{array}{c}\text { Probability > } \\
\text { reference }\end{array}$} & \multirow[b]{2}{*}{$N^{\mathrm{c}}$} & \multirow[b]{2}{*}{ Rating $^{\mathrm{d}}$} \\
\hline & & PA1 & PA2 & PA(1+2)-eBLUP & ВТМ & R-MR & S-VS & & \\
\hline 1 & CPI133872 & -3.783 & 0.917 & 8.88 & 7,171 & 0 & 0 & 13 & $R$ \\
\hline 4 & QT8343 & -2.839 & -2.363 & 9.28 & 10,667 & 0.226 & 0 & 11 & R-MR \\
\hline 5 & QT9048 & -2.694 & -1.186 & 9.36 & 11,625 & 0.425 & 0 & 9 & R-MR \\
\hline 6 & $G S 50 a$ & -2.666 & -0.040 & 9.39 & 11,991 & $N A$ & 0 & 22 & $R-M R$ \\
\hline 14 & Impose CL Plus & -2.488 & 1.243 & 9.49 & 13,279 & 0.694 & 0 & 4 & MR \\
\hline 17 & QT9050 & -2.246 & -0.232 & 9.59 & 14,573 & 0.908 & 0 & 12 & MR \\
\hline 20 & $Q T 8447$ & -2.086 & 0.577 & 9.67 & 15,898 & 0.969 & 0 & 12 & $M R$ \\
\hline 24 & Wyalkatchem & -1.937 & 0.657 & 9.75 & 17,085 & 0.946 & 0 & 5 & $\mathrm{MR}$ \\
\hline 28 & Bolac & -1.790 & 0.356 & 9.81 & 18,214 & 0.967 & 0 & 4 & MR-MS \\
\hline 30 & Kiora & -1.728 & -0.748 & 9.82 & 18,471 & 0.955 & 0 & 4 & MR-MS \\
\hline 34 & Gauntlet & -1.716 & -0.355 & 9.84 & 18,675 & 0.989 & 0 & 5 & MR-MS \\
\hline 40 & Sunmate & -1.594 & -0.700 & 9.89 & 19,672 & 0.974 & 0 & 4 & MR-MS \\
\hline 41 & Amarok & -1.597 & -0.529 & 9.89 & 19,711 & 0.988 & 0 & 5 & MR-MS \\
\hline 51 & Corack & -1.523 & 1.016 & 9.95 & 20,868 & 0.996 & 0 & 4 & MR-MS \\
\hline 62 & Wallup & -1.368 & 0.329 & 10.01 & 22,225 & 0.999 & 0 & 4 & MR-MS \\
\hline 65 & Suntime & -1.305 & -0.389 & 10.03 & 22,674 & 0.994 & 0 & 4 & MR-MS \\
\hline 73 & Suntop & -1.244 & -0.979 & 10.05 & 23,132 & 0.999 & 0 & 4 & $M R-M S$ \\
\hline 75 & Ventura & -1.249 & 0.038 & 10.06 & 23,411 & 1 & 0 & 9 & MR-MS \\
\hline 79 & Chara & -1.219 & -0.059 & 10.07 & 23,717 & 1 & 0 & 11 & MS \\
\hline 107 & Glover & -1.026 & 0.048 & 10.17 & 26,029 & 1 & 0 & 5 & MS \\
\hline 120 & Hartog & -0.995 & 0.541 & 10.19 & 26,608 & 1 & 0 & 14 & $M S$ \\
\hline 145 & Sunzell & -0.845 & -0.091 & 10.25 & 28,282 & 1 & 0 & 5 & MS \\
\hline 191 & Leichhardt & -0.651 & -0.267 & 10.34 & 30,914 & 1 & 0 & 11 & MS \\
\hline 287 & Sunvale & -0.412 & -0.517 & 10.45 & 34,474 & 1 & 0 & 11 & MS-S \\
\hline 310 & Kidman & -0.385 & 0.000 & 10.47 & 35,206 & 1 & 0 & 5 & MS-S \\
\hline 329 & Giles & -0.338 & 0.172 & 10.49 & 36,061 & 1 & 0 & 11 & MS-S \\
\hline 347 & Gregory & -0.264 & -0.532 & 10.52 & 36,974 & 1 & 0 & 10 & $M S-S$ \\
\hline 374 & Spitfire & -0.169 & -1.272 & 10.55 & 38,253 & 1 & 0.002 & 5 & MS-S \\
\hline 378 & Yenda & -0.189 & -0.420 & 10.56 & 38,368 & 1 & 0.004 & 4 & MS-S \\
\hline 384 & Wylie & -0.213 & 0.712 & 10.56 & 38,560 & 1 & 0 & 9 & MS-S \\
\hline 425 & Bowerbird & -0.077 & -0.443 & 10.61 & 40,416 & 1 & 0.001 & 6 & MS-S \\
\hline 437 & Baxter & -0.029 & -1.548 & 10.61 & 40,700 & 1 & 0 & 12 & MS-S \\
\hline 557 & Sunco & 0.142 & -1.254 & 10.70 & 44,311 & 1 & 0.003 & 11 & S \\
\hline 10 & Lang & 0.214 & -0.874 & 10.74 & 46,119 & 1 & 0.005 & 11 & $\mathrm{~S}$ \\
\hline 654 & Batavia & 0.204 & 2.060 & 10.78 & 47,905 & 1 & 0.003 & 21 & $\mathrm{~S}$ \\
\hline 659 & Hume & 0.260 & 0.687 & 10.78 & 48,193 & 1 & 0.014 & 9 & $\mathrm{~S}$ \\
\hline 663 & Sunguard & 0.284 & -0.020 & 10.78 & 48,242 & 1 & 0.029 & 5 & $\mathrm{~S}$ \\
\hline 674 & Sunvex & 0.278 & 0.520 & 10.79 & 48,484 & 1 & 0.054 & 5 & $\mathrm{~S}$ \\
\hline 688 & Waagan & 0.327 & 0.119 & 10.81 & 49,315 & 1 & 0.049 & 6 & $\mathrm{~S}$ \\
\hline 691 & Banks & 0.375 & -1.295 & 10.81 & 49,414 & 1 & 0.016 & 11 & $\mathrm{~S}$ \\
\hline 715 & Crusader & 0.399 & -0.151 & 10.84 & 50,817 & 1 & 0.058 & 6 & $\mathrm{~S}$ \\
\hline 816 & Cunningham & 0.547 & -0.050 & 10.91 & 54,611 & 1 & 0.049 & 12 & $S$ \\
\hline 905 & Janz & 0.675 & 0.579 & 10.98 & 58,512 & 1 & 0.100 & 13 & S-VS \\
\hline 935 & Babbler & 0.781 & -0.530 & 11.01 & 60,535 & 1 & 0.186 & 4 & S-VS \\
\hline 936 & Stampede & 0.772 & 0.139 & 11.02 & 60,839 & 1 & 0.219 & 6 & S-VS \\
\hline 60 & Strzelecki & 0.815 & 0.261 & 11.04 & 62,254 & 1 & 0.185 & 10 & $S-V S$ \\
\hline 998 & Kennedy & 0.962 & -0.872 & 11.09 & 65,577 & 1 & 0.263 & 13 & S-VS \\
\hline 1,002 & H91 & 0.956 & -0.128 & 11.10 & 66,104 & 1 & 0.313 & 4 & S-VS \\
\hline 1,004 & Kukri & 0.968 & -0.423 & 11.10 & 66,236 & 1 & 0.317 & 4 & S-VS \\
\hline 1,008 & Gazelle & 0.991 & -0.712 & 11.11 & 66,635 & 1 & 0.315 & 5 & S-VS \\
\hline 1,018 & Gatcher & 0.970 & 0.785 & 11.12 & 67,507 & 1 & 0.314 & 18 & S-VS \\
\hline 1,054 & Impala & 1.162 & -0.359 & 11.19 & 72,619 & 1 & 0.481 & 5 & S-VS \\
\hline 1,059 & Yandanooka & 1.210 & -1.222 & 11.20 & 73,423 & 1 & NA & 9 & S-VS \\
\hline 1,070 & Lincoln & 1.243 & 1.158 & 11.25 & 77,187 & 1 & 0.581 & 4 & S-VS \\
\hline 1,079 & Forrest & 1.380 & 0.176 & 11.30 & 81,145 & 1 & 0.684 & 5 & VS \\
\hline 1,083 & Annuello & 1.445 & -0.175 & 11.33 & 83,199 & 1 & 0.699 & 4 & VS \\
\hline 1,084 & Wedgetail & 1.421 & 0.675 & 11.33 & 83,365 & 1 & 0.722 & 5 & VS \\
\hline 1,091 & Brennan & 1.581 & -0.050 & 11.40 & 88,875 & 1 & 0.803 & 5 & VS \\
\hline 1,095 & Petrie & 1.719 & -0.356 & 11.46 & 94,465 & 1 & 0.916 & 11 & $V S$ \\
\hline 1,096 & Darwin & 1.893 & 0.714 & 11.55 & 104,192 & 1 & 0.901 & 4 & VS \\
\hline
\end{tabular}

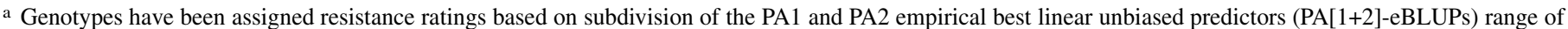
natural logarithm $(\ln )(P$. thornei nematodes per kilogram of soil) into nine arithmetically equal categories. BTM = back-transformed means by exponentiation. Probabilities of values greater than the reference genotypes GS50a (R-MR) and Yandanooka (S-VS) proposed by Sheedy et al. (2015) are given. NA = not applicable. Derived resistance ratings are $\mathrm{R}=$ resistant, $\mathrm{R}-\mathrm{MR}=$ resistant to moderately resistant, $\mathrm{MR}=$ moderately resistant, $\mathrm{MR}-\mathrm{MS}=\mathrm{moderately}$ resistant to moderately susceptible, $\mathrm{MS}=$ moderately susceptible, MS-S = moderately susceptible to susceptible, $\mathrm{S}=$ susceptible, $\mathrm{S}$-VS = susceptible to very susceptible, and $\mathrm{VS}=$ very susceptible. Genotypes chosen to be resistance references in these nine categories for future experiments are shown in italics.

b Reference rank.

c Number of experiments.

d The alpha resistance rating based on PA(1+2)-eBLUP. 
than a qualitative approach to characterizing the resistance to $P$. thornei is required in view of the knowledge that resistance to this nematode species is inherited quantitatively under the control of multiple genes having additive gene action (Thompson and Seymour 2011; Thompson et al. 2012b; Zwart et al. 2004).

The PA(1+2)-eBLUP values for genotypes were shown to be a valuable parameter in predicting relative field population densities of $P$. thornei developed under different wheat genotypes. These results validate the glasshouse methods for assessing resistance of wheat genotypes to $P$. thornei and provide confidence in the application of this information to field situations. Foremost among these applications are an ordinal alpha ratings for growers' sowing guides; however, they could also be valuable variables in crop growth models incorporating nematode population dynamics as influenced by wheat cultivar choice.
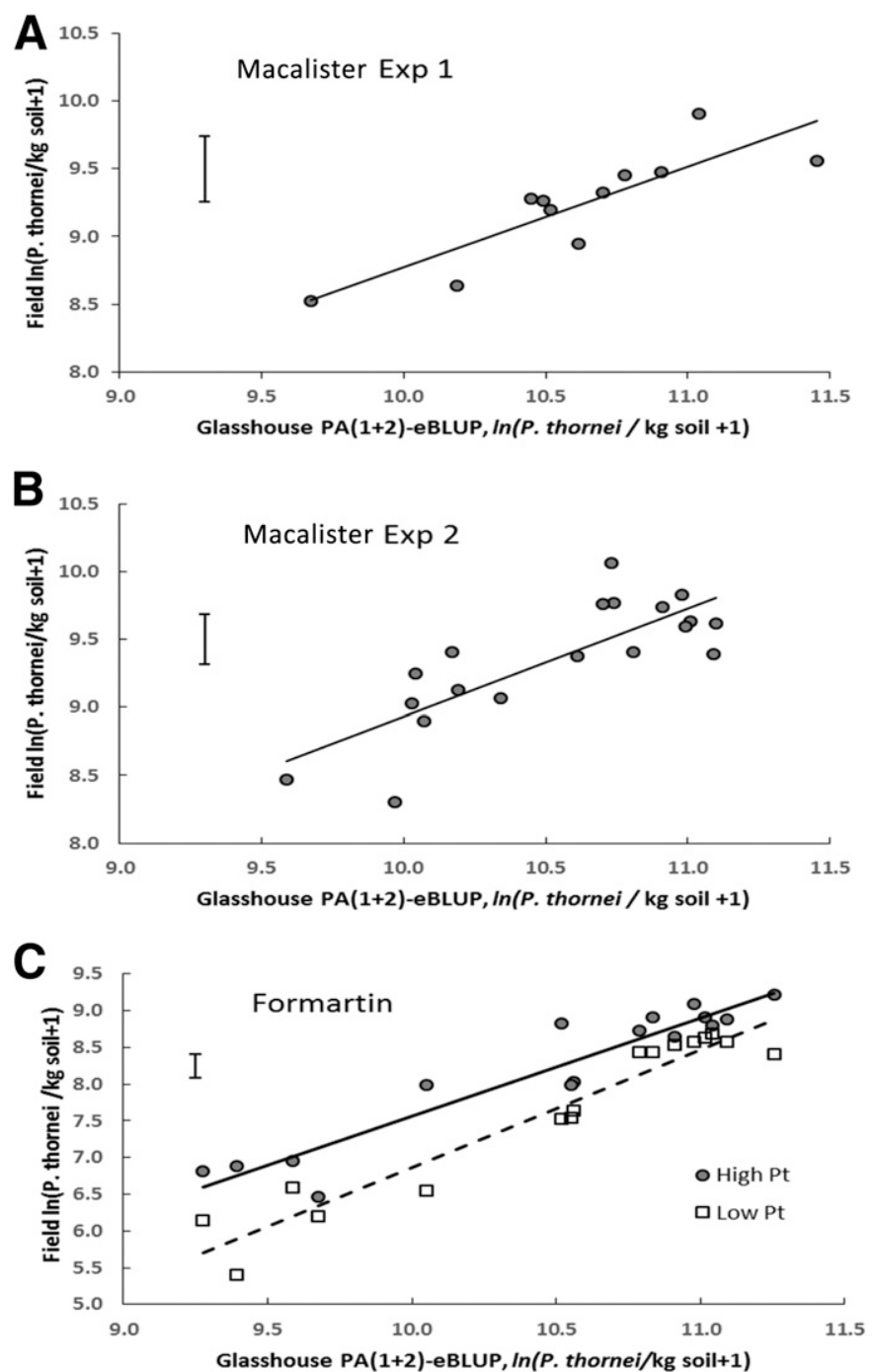

Fig. 3. Predictive ability of glasshouse-derived principal axes 1 and 2 empirical best linear unbiased predictors (PA[1+2]-eBLUPs) of natural logarithm (ln)(Pratylenchus thornei nematodes per kilogram of soil) for field population densities of $P$. thorne $i$ in the soil profile of two experiments at Macalister and one at Formartin for various wheat genotypes. Bar marker is least significant difference $(P=0.05)$. A, For Macalister experiment 1 , soil profile to $45-\mathrm{cm}$ depth, $F P D=0.744 G H B L U P+1.330, R^{2}=0.73, P<0.001, n=11$. B, for Macalister experiment 2, soil profile to 45 -cm depth, $F P D=0.76 G H B L U P+$ $1.330, R^{2}=0.65, P<0.001, n=19$. C, For Formartin, soil profile to $90-\mathrm{cm}$ depth at low P. thornei: $F P D=1.606 G H B L U P-9.20, R^{2}=0.92, P<0.001$, $n=16$, and at high $P$. thornei: $F P D=1.335 G H B L U P-5.78, R^{2}=0.89, P<$ $0.001, n=16 . F P D=$ field population density $\ln (P$. thorne $i$ nematodes per kilogram of soil +1$)$ and $G H B L U P=$ glasshouse $(\mathrm{PA} 1+2)$-eBLUP of $\ln (P$. thornei nematodes per kilogram of soil +1 ).
Previously, genetic correlation $(r>0.66)$ was found for data on $\mathrm{P}_{\mathrm{f}}$ of $P$. thornei between a single glasshouse experiment evaluating 47 genotypes of chickpea and six field experiments (five from the subtropical grain region and one from the warm temperate grain region of Victoria) sampled to either 15 or $30 \mathrm{~cm}$ of soil depth and evaluating a total of 85 chickpea genotypes in the one MET analysis (Rodda et al. 2016). Recently, high genetic correlation ( $r>0.9)$ was found between environments for population densities of $P$. thornei in the top soil ( 0 to 10 or 0 to $15 \mathrm{~cm}$ ) after harvest of 68 cereal genotypes in six field experiments in the temperate region of southern Australia, except where the fungal pathogen Rhizoctonia solani was damaging (Fanning et al. 2018). In the present study with wheat, we have preferred to analyze our glasshouse data in a MET analysis separately from any field data and then to use the output of the MET analysis to predict relative $P$. thorne $i$ population densities in the independent field experiments. This approach has validated our glasshouse methods for assessing $P$. thornei resistance of wheat genotypes and demonstrated their value for predicting relative final P. thornei population densities developed in the field when various wheat cultivars are grown. In addition, the glasshouse method provides surety of results each year compared with field testing, where some experiments can be lost through environmental
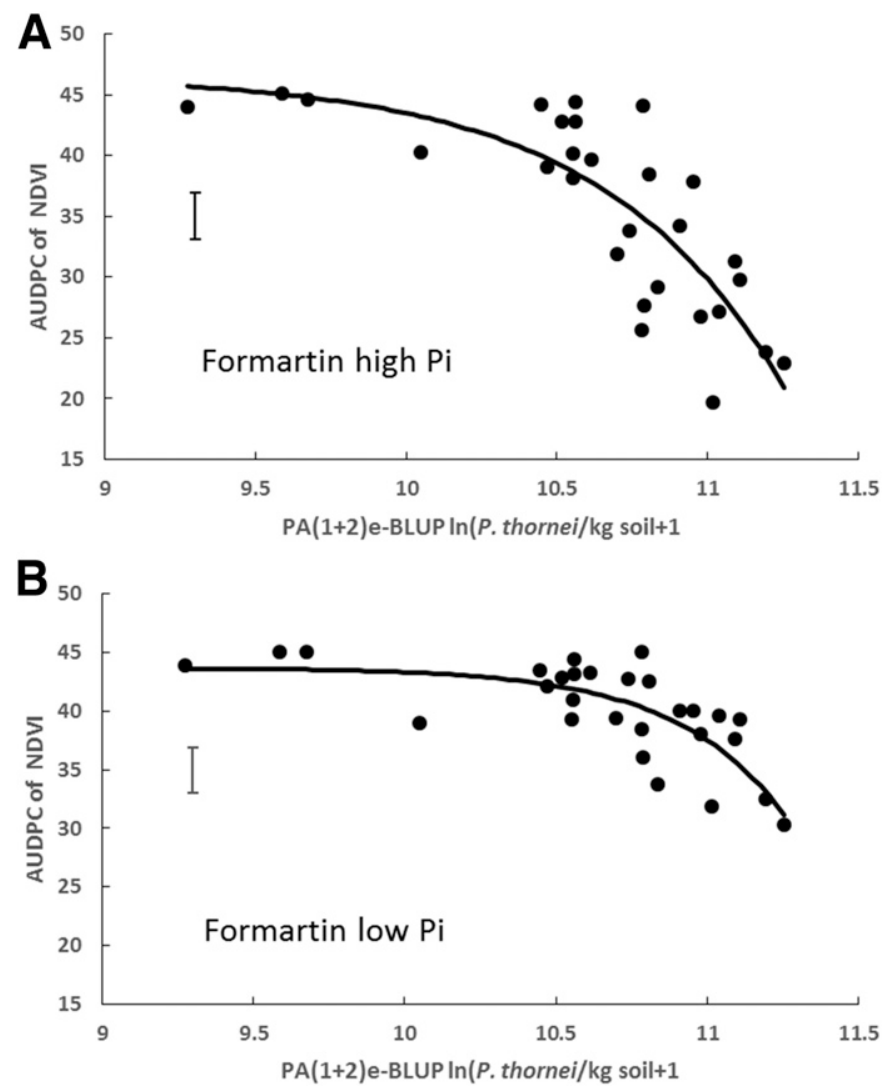

Fig. 4. Predictive ability of glasshouse-derived principal axes 1 and 2 empirical best linear unbiased predictors (PA[1+2]-eBLUPs) of natural logarithm (ln)(Pratylenchus thornei nematodes per kilogram of soil) for area under the disease progress curve (AUDPC) of seven measurements of crop greenness by normalized difference vegetation index (NDVI) at seven sensing times from 64 to 126 days after sowing of 28 wheat genotypes grown at two initial population densities of $P$. thornei at Formartin. Bar marker is least significant difference $(P=0.05)$. A, NDVI measurements at high initial population density $\left(\mathrm{P}_{\mathrm{i}}\right)$ of $P$. thornei: AUDPC $=46.63-0.00000016 \times 5.36^{(\text {GHBLUP) }}, R^{2}=0.62, P<0.001$, $n=28$. B, NDVI measurements at low $\mathrm{P}_{\mathrm{i}}$ of $P$. thornei: AUDPC $=43.7-$ $0.000000000000286 \times 16.3^{\text {(GHBLUP) }}, R^{2}=0.54, P<0.001, n=28$. AUDPC was measured in NDVI units and $G H B L U P=\mathrm{PA}(1+2)$-eBLUPs of $\ln$ (final population density of $P$. thornei nematodes per kilogram of soil) from combined glasshouse experiments. 
extremes such as drought, flood, and hail or pests such as feral animals or fungal diseases. In contrast, only one glasshouse experiment-namely, that conducted in 2004-was deemed unsuitable for combined analysis because of aberrant results caused by manually processing the soil for nematode extraction when it was too wet.

In the deep clay soils of the subtropical grain region of Australia, $P$. thornei can occur in the soil profile to a $90-\mathrm{cm}$ depth. Our results showed that the genotype PA $(1+2)$-eBLUPs from the combined glasshouse experiments were predictive of the genotype $P_{\mathrm{f}}$ to depths of $45 \mathrm{~cm}$ at Macalister and $90 \mathrm{~cm}$ at Formartin. This shows the influence of growing different wheat genotypes on $P$. thornei population densities throughout the soil profile, and that the combined analysis of the glasshouse experiments as described provides measures that can be used to rank genotypes on how they affect nematode population densities throughout the whole soil profile.

To produce resistance ratings of cultivars for wheat sowing guides, the subdivision of the range of PA(1+2)-eBLUPs into nine equal classes converted to nine $\alpha$ ratings as required is a useful simplification but, for other purposes, the numeric values of PA(1+2)-eBLUPs are preferable. Each year, there is a requirement to assess prospective new cultivars for resistance to $P$. thornei and our established database is an asset for this purpose. Adding new experimental data to the existing database for MET analysis will allow new wheat genotypes to be assessed reliably for resistance
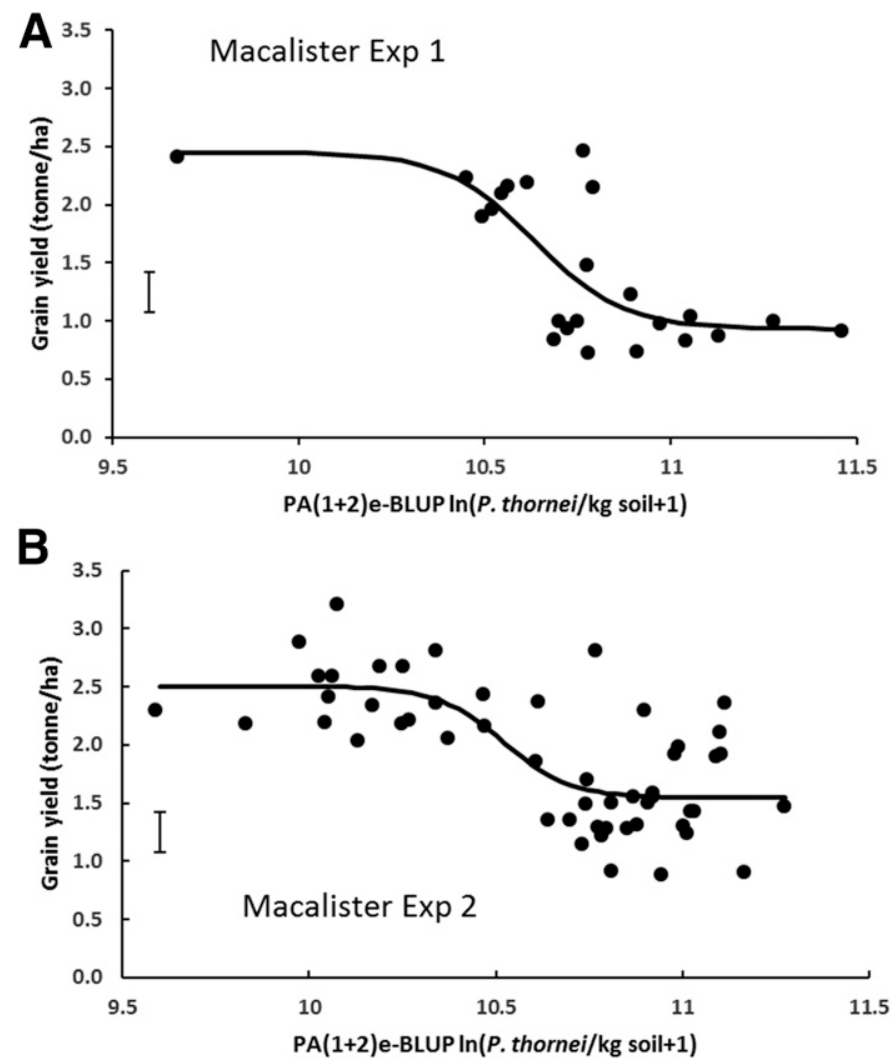

Fig. 5. Predictive ability of glasshouse-derived principal axes 1 and 2 empirical best linear unbiased predictors (PA[1+2]-eBLUPs) of natural logarithm (In)(Pratylenchus thornei nematodes per kilogram of soil) for grain yield of wheat cultivars in a $P$. thornei-infested field at Macalister for 23 late-maturing wheat genotypes in experiment 1 and 52 main-maturity wheat genotypes in experiment 2 . Bar marker is least significant difference $(P=0.05)$. A, Grain yield in experiment 1: $G Y=0.931+1.519 /\{1+\exp [8.44 \times(G H B L U P-$ 10.632)] $\}, R^{2}=0.47, P<0.002, n=23$. B, Grain yield in experiment 2: $G Y=$ $1.546+0.9589 /\{1+\exp [11.31 \times($ GHBLUP -10.52$)]\}, R^{2}=0.50, P<0.001$, $n=52 . G Y=$ grain yield $(\mathrm{t} / \mathrm{ha})$ and $G H B L U P=\mathrm{PA}(1+2)$-eBLUPs of $\ln (\mathrm{final}$ population density of $P$. thornei nematodes per kilogram of soil) from combined glasshouse experiments. within the framework of covariance across experiments through concurrence of other genotypes, including the reference set. We are applying a similar approach to analysis of glasshouse resistance experiments for $P$. neglectus of wheat genotypes for growers' sowing guides (Lush 2018; Matthews et al. 2017), and the methods used here could be useful in other crops and with other nematode species.

The fact that the wheat genotypes in this study are representative of Australian cultivars and plant breeders' advanced breeding lines and that most were found to be susceptible to very susceptible to $P$. thorne $i$ indicates the need for concerted efforts to improve resistance levels. Excellent levels of resistance have been identified in several unadapted germplasm sources which are now being hybridized into adapted wheat backgrounds for plant
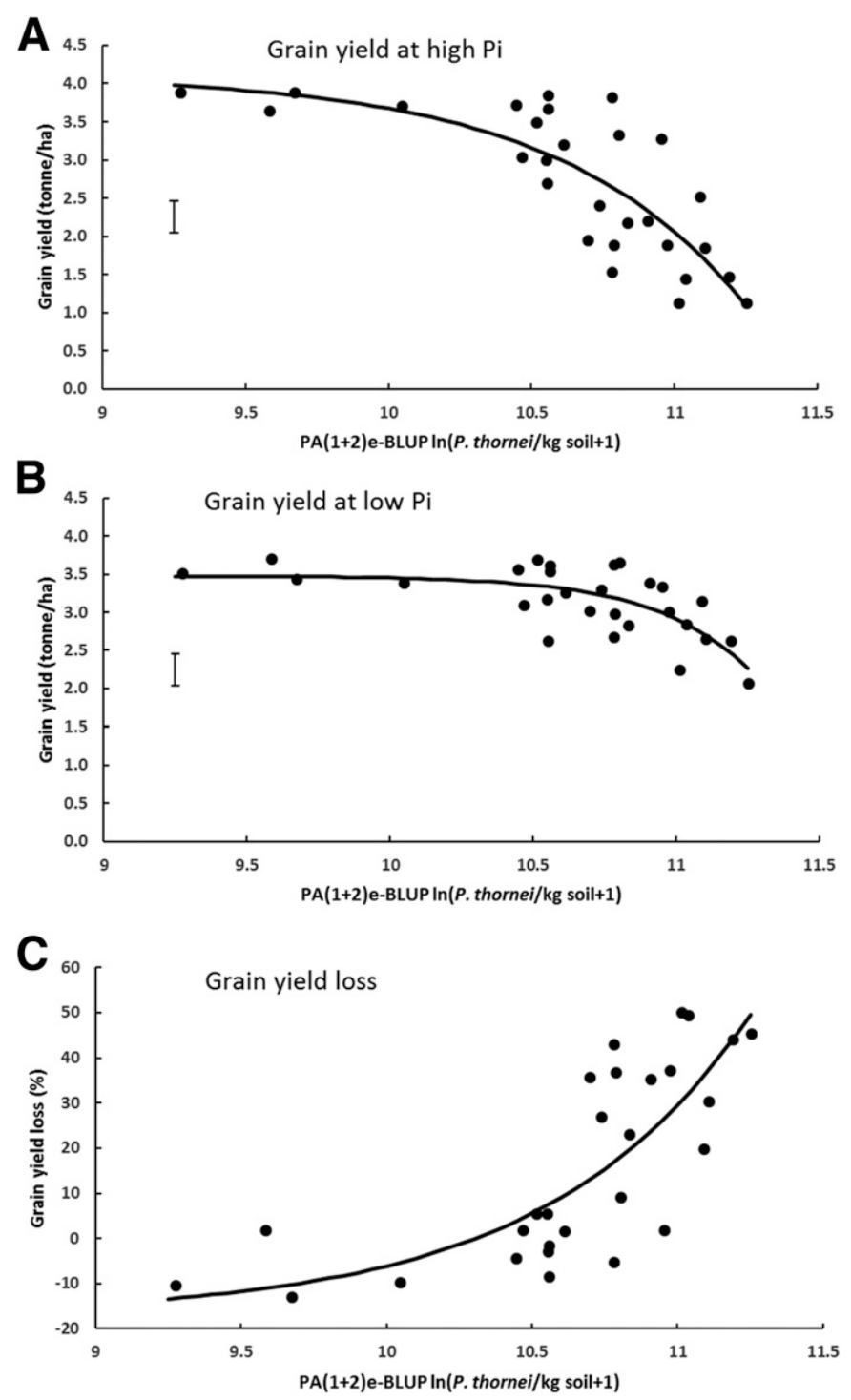

Fig. 6. Predictive ability of glasshouse-derived principal axes 1 and 2 empirical best linear unbiased predictors (PA[1+2]-eBLUPs) of natural logarithm (ln)(Pratylenchus thornei nematodes per kilogram of soil) for grain yield of wheat cultivars in a $P$. thornei-infested field at Formartin for 28 wheat genotypes grown with high and low initial population densities $\left(\mathrm{P}_{\mathrm{i}}\right)$ of $P$. thornei. Bar marker is least significant difference $(P=0.05)$. A, Grain yield at high $P$. thornei: $G Y=4.113-0.000000087 \times 4.68^{(G H B L U P)}, R^{2}=0.58, P<0.001, n=$ 28. B, Grain yield at low P. thornei: $G Y=3.477-0.0000000000101 \times$ 21. $9^{(G H B L U P)}, R^{2}=0.45, P<0.001, n=28$. C, Grain yield loss: $G Y=17.1-$ $0.000006 \times 4.23^{(G H B L U P)}, R^{2}=0.56, P<0.001, n=28 . G Y=$ grain yield $(\mathrm{t} / \mathrm{ha})$, $G Y L=$ grain yield loss $(\%)$, and $G H B L U P=\mathrm{PA}(1+2)$-eBLUPs of $\ln ($ final population density of $P$. thornei nematodes per kilogram of soil) in combined glasshouse experiments. $G Y L(\%)=100 \times\left[\left(G Y\right.\right.$ at low $\mathrm{P}_{\mathrm{i}}-G Y$ at high $\left.\mathrm{P}_{\mathrm{i}}\right) / G Y$ at low $\mathrm{P}_{\mathrm{i}}$ ]. 
breeders' use to produce more resistant cultivars for growers (Sheedy et al. 2017).

From analysis of six experiments comparing methods for testing for resistance to $P$. thornei, in which 23 bread wheat genotypes were evaluated, Sheedy et al. (2015) selected 7 for use as provisional reference cultivars for future experiments. The more comprehensive analyses reported here, with 1,096 genotypes and 22 experiments, have permitted an improved selection of reference cultivars. One genotype has been selected to represent the resistance level in each of nine ordered categories ranging from R to VS based on equal subdivision of the range of values for PA $(1+2)$-eBLUPs in units of $\ln (P$. thornei nematodes $/ \mathrm{kg}$ of soil $)$. These new reference genotypes for the nine resistance categories are $\mathrm{R}=\mathrm{CPI} 133872$, $\mathrm{R}-$ MR = GS50a, MR = QT8447, MR-MS = Suntop, MS = Hartog, MS$\mathrm{S}=$ Gregory, $\mathrm{S}=$ Cunningham, $\mathrm{S}-\mathrm{VS}=$ Strzelecki, and VS = Petrie. These reference genotypes have been selected based on their overall levels of resistance within each category and on a low standard error of the PA(1+2)-eBLUP. Of those reference genotypes suggested by Sheedy et al. (2015), CPI133872 has been retained to represent the $\mathrm{R}$ category and GS50a has been retained to represent the R-MR category of resistance. Other genotypes have been nominated for categories in which no reference genotype was nominated by Sheedy et al. (2015), while others have been replaced by preferred reference genotypes.

Growers are primarily interested in producing grain, and the capacity of wheat cultivars to do this under field environmental conditions in soil heavily infested with $P$. thornei in the subtropical grain region of eastern Australia is provided as tolerance ratings in sowing guides (Lush 2018). Resistance ratings are also provided in sowing guides and they are often regarded as a measure of the impact that a cultivar will have on the population densities of $P$. thornei residual in the soil to attack a subsequent crop. However, from this study, it is apparent that the level of resistance or susceptibility of crop cultivars is a major determinant of their growth and grain yield on sites infested with $P$. thornei in this region. This effect of resistance on plant growth was illustrated diagrammatically by Roberts (2002), in which a resistant genotype produced not only fewer nematodes but also a larger plant than a tolerant genotype that allowed greater nematode reproduction. Clearly, because of the polycyclic nature of $P$. thornei, as the nematode numbers increase in the roots of susceptible wheat genotypes they cause more damage to the plant root systems, which results in poorer vegetative growth and grain yield than in wheat genotypes with greater levels of resistance. This better comprehension of the role that resistance plays in $P$. thornei population changes and grain yield of wheat cultivars in the subtropical grain region of

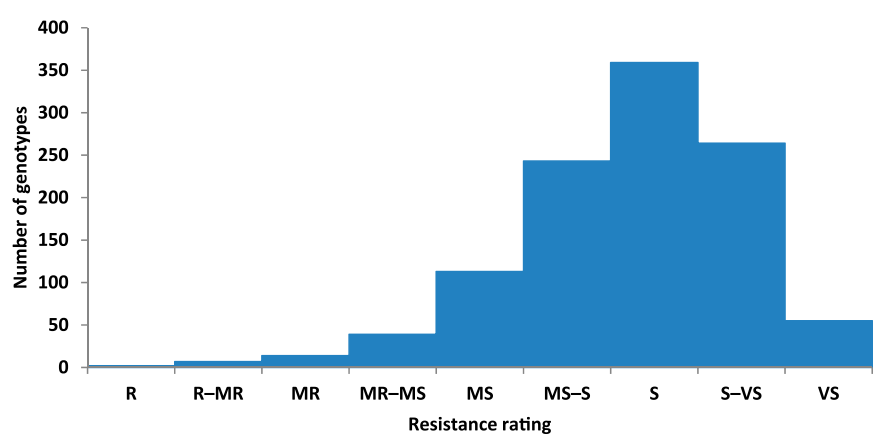

Fig. 7. Distribution of predicted population densities of Pratylenchus thornei based on equal subdivision of the range of principal axes 1 and 2 empirical best linear unbiased predictors (PA[1+2]-eBLUPs) in natural logarithm $(\ln )(P$. thornei nematodes per kilogram of soil +1) units for 1,096 wheat genotypes from 22 experiments shown as nine corresponding $\alpha$ resistance ratings, where $\mathrm{R}=$ resistant, $\mathrm{R}-\mathrm{MR}=$ resistant to moderately resistant, $\mathrm{MR}=$ moderately resistant, MR-MS = moderately resistant to moderately susceptible, $\mathrm{MS}=$ moderately susceptible, MS-S = moderately susceptible to susceptible, $\mathrm{S}=$ susceptible, $\mathrm{S}-\mathrm{VS}=$ susceptible to very susceptible, and VS = very susceptible.
Australia emphasizes the value of genetic resistance for growers, the importance of the trait as a target for wheat breeding, and the ongoing need to accurately characterize the resistance to $P$. thorne $i$ of all wheat cultivars to be released by plant breeding companies for growers' use.

In summary, combining data on $\mathrm{P}_{\mathrm{f}}$ of $P$. thornei for 1,096 wheat genotypes in 22 glasshouse experiments by a MET analysis was an effective way to compare the resistance of wheat genotypes. A twofactor model explained $90 \%$ of the genetic variance, with $79 \%$ of the genetic variance accounted for in PA1, regarded as a stable resistance axis, reflecting the high genetic correlation among experiments. PA2 explained an additional $11 \%$ of the genetic variance, indicating that the resistance levels of some genotypes could not be fully explained by PA1 alone. Genotype scores of PA(1+2)-eBLUPs in units of $\ln (P$. thornei nematodes $/ \mathrm{kg}$ of soil +1$)$ from these glasshouse results were highly predictive of relative $P_{f}$ of $P$. thornei to depth in the soil profile after growth of various wheat genotypes in three field experiments. There were also highly significant nonlinear relationships between glasshouse-derived resistance levels and genotype performance in the field assessed by greenness of vegetative biomass and grain yield. Subdivision of the range of $\mathrm{PA}(1+2)$-eBLUPs into nine subranges is presented as an objective method for producing ordinal or alpha resistance ratings for growers' sowing guides. The majority of genotypes tested were in the top three susceptibility ratings, indicating the need for continued germplasm development to raise the level of resistance to $P$. thornei in wheat cultivars available to Australian growers.

\section{ACKNOWLEDGMENTS}

We thank T. Clewett, M. O'Reilly, M. Thompson, J. Lin, R. Reen, M. Wang, H. Rostad, A. Skerman, I. Dempsey, J. McLean, T. Bull, and D. Lush for their assistance at various times in the conduct of the glasshouse and field experiments; and A. Gwynne (Formartin) and R. Taylor (Macalister) for generously supplying farm land for field experiments.

\section{LITERATURE CITED}

Beckmann, G. G., and Thompson, C. H. 1960. Soils and Land Use in the Kurrawa Area, Darling Downs, Queensland. CSIRO Division of Soils, Soils Land Use Ser. No. 37. CSIRO, Melbourne, VIC, Australia.

Beeck, C., Cowling, W. A., Smith, A. B., and Cullis, B. R. 2010. Analysis of yield and oil from a series of canola breeding trials. Part I. Fitting factor analytic mixed models with pedigree information. Genome 53:992-1001.

Butler, D. G., Cullis, B. R., Gilmour, A. R., and Gogel, B. J. 2009. ASReml-R Reference Manual. Tech. Rep. 3. Queensland Department of Agriculture, Fisheries and Forestry, Brisbane, QLD, Australia.

Cullis, B. R., Smith, A. B., Beeck, C. P., and Cowling, W. A. 2010. Analysis of yield and oil from a series of canola breeding trials. Part II. Exploring variety by environment interaction using factor analysis. Genome 53:1002-1016.

De Waele, D., and Elsen, A. 2002. Migratory endoparasites: Pratylenchus and Radopholus species. Pages 175-206 in: Plant Resistance to Parasitic Nematodes. J. L. Starr, R. Cook, and J. Bridge, eds. CABI Publishing, Wallingford, U.K.

Fanning, J., Linsell, K., McKay, A., Gogel, B., Munoz Santa, I., Davey, R., and Hollaway, G. 2018. Resistance to the root lesion nematodes Pratylenchus thornei and P. neglectus in cereals: Improved assessments in the field. Appl. Soil Ecol. 132:146-154.

Farsi, M., Vanstone, V. A., Fisher, J. M., and Rathjen, A. J. 1995. Genetic variation in resistance to Pratylenchus neglectus in wheat and triticales. Aust. J. Exp. Agric. 35:597-602.

Fortuner, R. 1977. Pratylenchus thornei. In: C.I.H. Description of PlantParasitic Nematodes, Set 7. Commonwealth Institute of Helminthology, Commonwealth Agricultural Bureaux, Farnham Royal, Slough, U.K.

Gilmour, A. R., Cullis, R. R., and Verbyla, A. P. 1997. Accounting for natural and extraneous variation in the analysis of field experiments. J. Agric. Biol. Environ. Stat. 2:269-293.

Harris, P., Biggs, A. J. W., Stone, B. J., Crane, L. N., and Douglas, N. J. 1999. Resource information book. in: Central Darling Downs Land Management Manual DNRQ990102. Queensland Department of Natural Resources, Brisbane, QLD, Australia.

Isbell, R. F. 1996. The Australian Soil Classification, Rev. ed. CSIRO Publishing, Melbourne, VIC, Australia. 
Kelly, A., Smith, A., Eccleston, J., and Cullis, B. R. 2007. The accuracy of varietal selection using factor analytic models for multi-environment plant breeding trials. Crop Sci. 47:1063-1070.

Lush, D. 2018. 2018 Wheat Varieties-Queensland. Grains Research and Development Corporation and the Queensland Department of Agriculture and Fisheries, Brisbane, QLD, Australia.

Matthews, P., McCaffery, D., and Jenkins, L. 2017. Winter Crop Variety Sowing Guide 2017. NSW Department of Primary Industries, Sydney, NSW, Australia.

Murray, G. M., and Brennan, J. P. 2009. Estimating disease losses to the Australian wheat industry. Australas. Plant Pathol. 38:558-570.

Nombela, G., and Romero, M. D. 2001. Field response to Pratylenchus thornei of a wheat line with the CreAet gene for resistance to Heterodera avenae. Eur. J. Plant Pathol. 107:749-755.

O'Reilly, M. M., and Thompson, J. P. 1993. Open pot culture proved more convenient that carrot callus culture for producing Pratylenchus thornei inoculum for glasshouse experiments. Pages 5-9 in Proc. Pratylenchus Workshop, Australas. Plant Pathol. Soc. Conf. Hobart, TAS, Australia.

Owen, K. J., Clewett, T. G., and Thompson, J. P. 2012. What is the impact of winter grain crops on Pratylenchus thornei grown in rotation with tolerant and intolerant wheat? Page 31 in: Proc. 7th Australas. Soilborne Dis. Symp. W. J. Macleod, ed. Fremantle, WA, U.S.A.

Owen, K. J., Clewett, T. G., and Thompson, J. P. 2014. Wheat biomass and yield increased when populations of the root-lesion nematode (Pratylenchus thornei) were reduced through sequential rotation of partially-resistant winter and summer crops. Crop Pasture Sci. 65:227-241.

Patterson, H. D., and Thompson, R. 1971. Recovery of inter-block information when block sizes are unequal. Biometrika 58:545-554.

PennState Extension. 2017. Pythium. Extension. https://extension.psu.edu/ pythium

Piepho, H.-P. 1998. Empirical best linear unbiased prediction in cultivar trials using factor-analytic variance-covariance structures. Theor. Appl. Genet. 97:195-201.

R Core Team. 2016. R: A Language and Environment for Statistical Computing. R Foundation for Statistical Computing, Vienna, Austria. https:// www.R-project.org/

Reen, R. A., Thompson, J. P., Clewett, T. G., Sheedy, J. G., and Bell, K. L. 2014. Yield response in chickpea cultivars and wheat following crop rotations affecting population densities of Pratylenchus thornei and arbuscular mycorrhizal fungi. Crop Pasture Sci. 65:428-441.

Roberts, P. A. 2002. Concepts and consequences of resistance. Pages 23-41 in: Plant Resistance to Parasitic Nematodes. J. L. Starr, R. Cook, and J. Bridge, eds. CABI Publishing, Wallingford, U.K.

Robinson, G. K. 1991. That BLUP is a good thing: The estimation of random effects. Stat. Sci. 6:15-32.

Robinson, N. A., Sheedy, J. G., MacDonald, B. J., Owen, K. J., and Thompson, J. P. 2019. Tolerance of wheat cultivars to root-lesion nematode (Pratylenchus thornei) assessed by normalised difference vegetation index is predictive of grain yield. Ann. Appl. Biol. 174:388-401.

Rodda, M. S., Hobson, K. B., Forknall, C. R., Daniel, R. P., Fanning, J. P., Pounsett, D. D., Simpfendorfer, S., Moore, K. J., Owen, K. J., Sheedy, J. G., Thompson, J. P., Hollaway, G. J., and Slater, A. T. 2016. Highly heritable resistance to root-lesion nematode (Pratylenchus thornei) in Australian chickpea germplasm observed using an optimised glasshouse method and multi-environment trial analysis. Australas. Plant Pathol. 45:309-319.

Romero, D., and Nombela, G. 1999. Host response to Pratylenchus thornei of a wheat line carrying the Cre 2 gene for resistance to Heterodera avenae. Nematology 1:381-388.

Sheedy, J. G., McKay, A. C., Lewis, J., Vanstone, V. A., Fletcher, S., Kelly, A., and Thompson, J. P. 2015. Cereal cultivars can be ranked consistently for resistance to root-lesion nematodes (Pratylenchus thornei \& P. neglectus) using diverse procedures. Australas. Plant Pathol. 44:175-182.

Sheedy, J. G., Robinson, N. A., Lin, J., Reen, R. A., Clewett, T. G., and Thompson, J. P. 2017. Pre-breeding to produce wheat cultivars that combine root-lesion nematode (Pratylenchus thornei and P. neglectus) resistance and tolerance. In: Aust. Wheat Breeders Assembly, Sydney, NSW, Australia.

Sheedy, J. G., and Thompson, J. P. 2009. Resistance to the root-lesion nematode Pratylenchus thornei of Iranian landrace wheat. Australas. Plant Pathol. 38:478-489.

Smiley, R. W., and Nicol, J. M. 2009. Nematodes which challenge global wheat production. Pages 71-187 in: Wheat Science and Trade. B. F. Carver, ed. Wiley-Blackwell, Ames, IA, U.S.A.

Smith, A. B., Cullis, B. R., and Thompson, R. 2001. Analysing variety by environment data using multiplicative mixed models and adjustments for spatial field trend. Biometrics 57:1138-1147.
Smith, A. B., Ganesalingam, A., Kuchel, H., and Cullis, B. R. 2015. Factor analytic mixed models for the provision of grower information from national crop variety testing programs. Theor. Appl. Genet. 128:55-72.

Thompson, C. H., and Beckmann, G. G. 1959. Soils in the Toowoomba area, Darling Downs, Queensland. CSIRO Australia, Soil and Land Use Series, No. 28. CSIRO, Melbourne, VIC, Australia.

Thompson, J. P. 1990a. Treatments to eliminate root-lesion nematode (Pratylenchus thornei Sher and Allen) from a vertisol. Nematologica 36: 123-127.

Thompson, J. P. 1990b. Soil sterilization methods to show VA-mycorrhizae aid $\mathrm{P}$ and $\mathrm{Zn}$ nutrition of wheat in vertisols. Soil Biol. Biochem. 22: 229-240.

Thompson, J. P. 2008. Resistance to root-lesion nematodes (Pratylenchus thornei and P. neglectus) in synthetic hexaploid wheats and their durum and Aegilops tauschii parents. Aust. J. Agric. Res. 59:432-446.

Thompson, J. P., Brennan, P. S., Clewett, T. G., Sheedy, J. G., and Seymour, N. P. 1999. Progress in breeding wheat for tolerance and resistance to rootlesion nematode (Pratylenchus thornei). Australas. Plant Pathol. 28:45-52.

Thompson, J. P., Clewett, T. G., and O'Reilly, M. M. 2015a. Optimising initial population density, growth time and nitrogen nutrition for assessing resistance of wheat cultivars to root-lesion nematode (Pratylenchus thornei). Australas. Plant Pathol. 44:133-147.

Thompson, J. P., Clewett, T. G., and O'Reilly, M. M. 2015b. Temperature response of root-lesion nematode (Pratylenchus thornei) reproduction on wheat cultivars has implications for resistance screening and wheat production. Ann. Appl. Biol. 167:1-10.

Thompson, J. P., and Haak, M. I. 1997. Resistance to root-lesion nematode (Pratylenchus thornei) in Aegilops tauschii Coss., the D-genome donor to wheat. Aust. J. Agric. Res. 48:553-559.

Thompson, J. P., Mackenzie, J., and Sheedy, G. H. 2012a. Root-lesion nematode (Pratylenchus thornei) reduces nutrient response, biomass and yield of wheat in sorghum-fallow-wheat cropping systems in a subtropical environment. Field Crops Res. 137:126-140.

Thompson, J. P., Owen, K. J., Stirling, G. R., and Bell, M. J. 2008. Root-lesion nematodes (Pratylenchus thornei and $P$ neglectus): A review of recent progress in managing a significant pest of grain crops in northern Australia. Australas. Plant Pathol. 37:235-242.

Thompson, J. P., Reen, R. A., Clewett, T. G., Sheedy, J. G., Kelly, A. M., Gogel, B. J., and Knights, E. J. 2011. Hybridisation of Australian chickpea cultivars with wild Cicer spp. increases resistance to root-lesion nematodes (Pratylenchus thornei and P. neglectus). Australas. Plant Pathol. 40:601-611.

Thompson, J. P., and Seymour, N. P. 2011. Inheritance of resistance to rootlesion nematode (Pratylenchus thornei) in wheat landraces and cultivars from the West Asia and North Africa (WANA) region. Crop Pasture Sci. 62: $82-93$.

Thompson, J. P., Zwart, R. S., and Butler, D. 2012b. Inheritance of resistance to root-lesion nematodes (Pratylenchus thornei and P. neglectus) in five doubled-haploid populations of wheat. Euphytica 188:209-219.

Trudgill, D. L. 1991. Resistance and tolerance of plant parasitic nematodes in plants. Annu. Rev. Phytopathol. 29:167-192.

VSN International. 2014. GenStat for Windows, 17th ed. VSN International, Hemel Hempstead, U.K. https://www.vsni.co.uk/software/genstat/

Wallace, H. R. 1987. A perception of tolerance. Nematologica 33:419-432.

Webb, A. A., Grundy, M. J., Powell, B., and Littleboy, M. 1997. The Australian subtropical cereal belt: Soils, climate and agriculture. Pages 8-23 in: Sustainable Crop Production in the Sub-tropics: An Australian Perspective. A. L. Clarke and P. B. Wylie, eds. Queensland Department of Primary Industries, Toowomba, QLD, Australia.

Whish, J. P. M., Thompson, J. P., Clewett, T. G., Lawrence, J. L., and Wood, J. 2014. Pratylenchus thornei populations reduce water uptake in intolerant wheat cultivars. Field Crops Res. 161:1-10.

Whish, J. P. M., Thompson, J. P., Clewett, T. G., Wood, J., and Rostad, H. E. 2017. Predicting the slow decline of root-lesion nematode (Pratylenchus thornei) during host-free fallows to improve farm management decisions. Eur. J. Agron. 91:44-53.

Whitehead, A. G., and Hemming, J. R. 1965. A comparison of some quantitative methods of extracting small vermiform nematodes from soil. Ann. Appl. Biol. 55:25-38.

Williams, E. R. 1986. Row and column designs with contiguous replicates. Aust. J. Stat. 28:154-163.

Zwart, R. S., Thompson, J. P., and Godwin, I. D. 2004. Genetic analysis of resistance to root-lesion nematode (Pratylenchus thornei) in wheat. Plant Breed. 123:209-212. 